\title{
Low-Level Jet Development during a Numerically Simulated Return Flow Event
}

\author{
Richard C. IgAU AND JOHN W. NieLSEN-GAMmON \\ Cooperative Institute for Applied Meteorological Studies, Department of Meteorology, Texas A\&M University, College Station, Texas
}

(Manuscript received 8 May 1997, in final form 12 January 1998)

\section{ABSTRACT}

\begin{abstract}
The evolution of the southerly low-level jet (LLJ) during a return flow event is studied using output from the Penn State/NCAR Mesoscale Model (Version 4). Three geographically different southerly LLJs develop in the simulation: one over the southern Plains of the United States, a second southwest of Brownsville, Texas, and a third over the western Gulf of Mexico. The LLJ over the Plains is found to form first as an inertial oscillation and later as a response to lee troughing and an elevated mixed layer that develops over the region. Over Mexico, the temperature structure over the Altiplanicie Mexicana (Mexican High Plain) is responsible for a locally intense low-level pressure gradient east of the High Plain which remains nearly stationary over two diurnal cycles. The LLJ over the western Gulf of Mexico results largely from topographic blocking of the low-level southerly flow by the eastern end of the Neovolcanic Cordillera northwest of Veracruz, Mexico.

The evolution of the lower troposphere over the southern Plains resembles the Carlson and Ludlam conceptual model for a severe storm environment, but the structure of the return flow is complex. When midlevel westerlies are weak, mesoscale and boundary layer processes govern the development of LLJs. As the west and southwesterly winds increase with an approaching upper-level disturbance, synoptic influences overwhelm the mesoscale processes leading to a single, larger-scale LLJ.
\end{abstract}

\section{Introduction}

The formation of the severe storm environment in the southern Plains of the United States often begins after an intrusion of cool, dry air moves south over the North American continent to the Gulf of Mexico. After the air is warmed and moistened over the Gulf, it is drawn back northward in advance of the next approaching upperlevel trough from the west. This sequence of events is the "return flow cycle" (Crisp and Lewis 1992). According to the conceptual model developed by Carlson and coworkers (Carlson and Ludlam 1968; Carlson et al. 1980, Carlson et al. 1983; Benjamin and Carlson 1986), the warm moist air flowing northward from the Gulf of Mexico is overrun by an elevated mixed layer (EML), consisting of well-mixed boundary layer air from the elevated terrain to the west. This process also leads to the formation of a surface dryline (Schaefer 1974) where the warm, dry airstream from the west meets the moist airstream from the south. Often during the return flow, a southerly low-level jet (LLJ) develops which rapidly transports the modified air northward (Djurić and Damiani 1980). The development of the LLJ over the southern Plains and the western Gulf of Mexico

Corresponding author address: Dr. John W. Nielsen-Gammon, Department of Meteorology, Texas A\&M University, MS 3150, College Station, TX 77843-3150.

E-mail: n-g@tamu.edu during the return flow cycle is the primary focus of this paper.

During quiescent conditions, the Great Plains southerly LLJ is a nocturnal phenomenon. The wind hodograph traces a near circle, with maximum supergeostrophic winds in the middle of the night (Bonner 1968; Bonner and Paegle 1970). This hodograph is the response of air parcels to two oscillating forces in the boundary layer (Bonner and Paegle 1970; Paegle and Rasch 1973; Parish et al. 1988), either of which can produce a rotating hodograph by itself. The first is the diurnally varying frictional force, whereby the decoupling of the boundary layer at night triggers an inertial oscillation (Blackadar 1957). This mechanism is enhanced by the time-mean temperature gradient produced by the surface radiative heating/cooling along the sloping terrain of the Great Plains (Bonner 1968; McNider and Pielke 1981), which yields a thermal wind opposing the low-level geostrophic wind (Zeman 1979). The second is the diurnal variation of the pressure gradient force caused by the alternating daytime heating and nighttime cooling along the sloping terrain (Holton 1967), which effectively produces a large-scale slope flow whose direction continually rotates through the action of the Coriolis force. There is evidence from individual cases (e.g., Savijärvi 1991; Frisch et al. 1992; Zhong et al. 1996) that the Blackadar mechanism may dominate. Both the time-mean temperature gradient and the diurnally varying temperature gradient (and consequently the strength of the LLJ) are enhanced by the typical variation of 


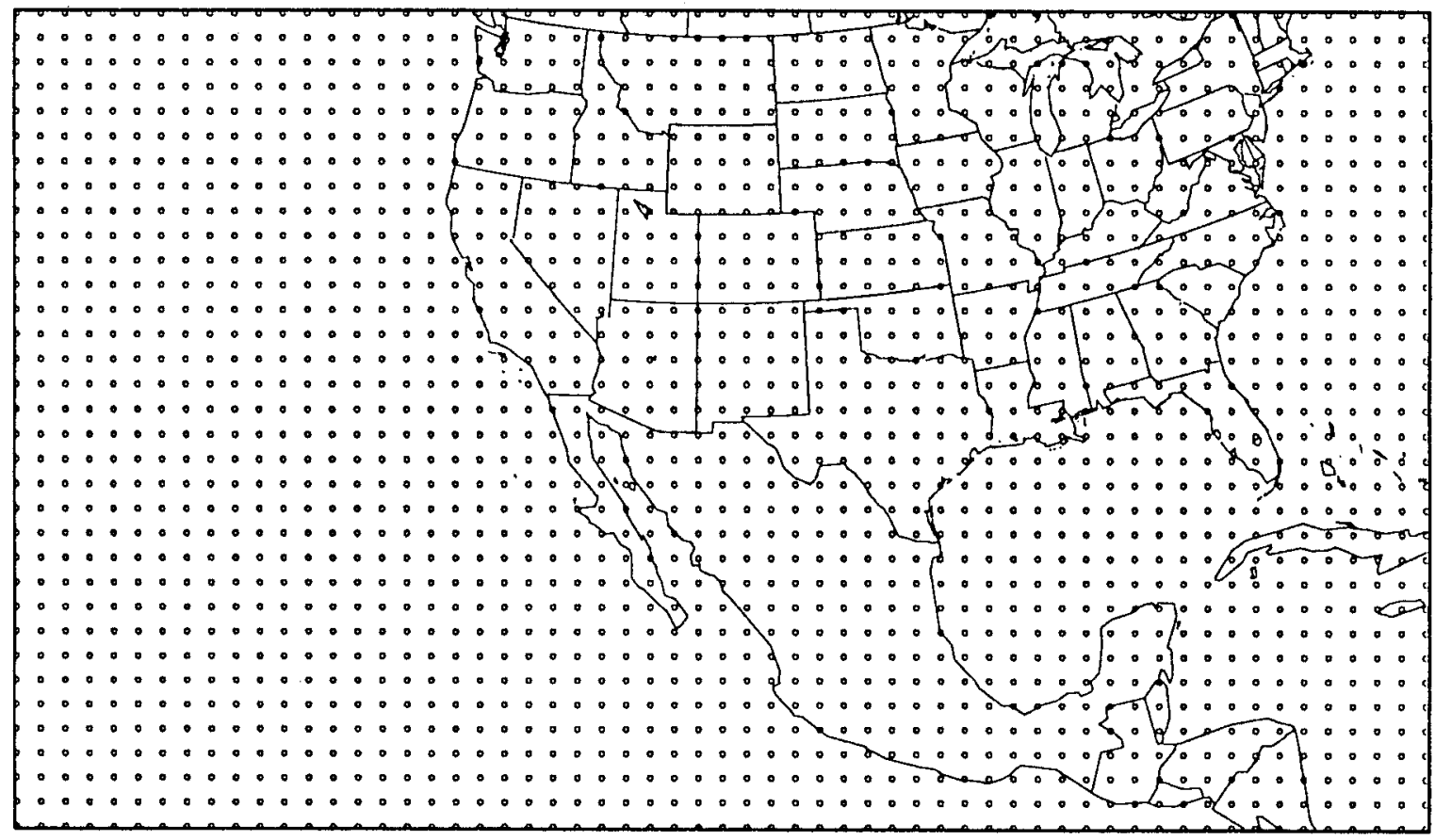

FIG. 1. Model domain. Alternating grid points are omitted for clarity.

surface moisture availability across the Great Plains: high in the east and low in the west (Fast and McCorcle 1990; McCorcle 1988), and would also be enhanced when soils are drier than normal (Fast and McCorcle 1990; Zhong et al. 1996). An additional minor contributor to jet intensity is the variation of the Coriolis parameter with latitude (Wexler 1961; Zhong et al. 1996).

LLJs also form in concert with evolving synopticscale pressure gradients associated with lee cyclogenesis. Here we refer to this environment as "active" rather than "quiescent." In the typical evolution, as described by Djurić and Damiani (1980) and Djurić and Ladwig (1983), a southerly wind first forms over the central Plains in response to the formation of a lee trough. During the next day, as the upper-level trough and surface front approach from the west, the low-level southerlies become widespread over the Plains of Oklahoma and Texas. With time, the LLJ spreads southward (i.e., upstream) to the Gulf of Mexico. While the quiescent LLJ is found at the base of the decoupled boundary layer, the LLJs associated with synoptic-scale cyclogenesis are somewhat deeper. The core of the jet tends to lie at the base of an inversion, which has been identified as a subsidence inversion (Djurić and Ladwig 1983), the remnants of the old cold front (Djurić and Ladwig 1983), or the base of the EML (Martin et al. 1995). Lanicci and Warner (1991) note that the LLJ composite maps of Djuric and Ladwig closely match their own EML/lid composites.

The extent to which this latter type of LLJ represents an unbalanced phenomenon is not known. Strong pressure gradients are characteristic of these LLJs, and an enhanced geostrophic wind would produce an enhanced inertial oscillation (Augustine and Caracena 1994). Uccellini (1980) noted that an integral part of many such LLJs appears to be the isallobaric wind response to lee cyclogenesis. Other synoptic-scale processes, such as a propagating jet streak (Uccellini and Johnson 1979) or latent heat release (Nicolini et al. 1993), also are capable of inducing or enhancing an ageostrophic low-level wind maximum. Mitchell et al. (1995) note that a variety of mechanisms, both synoptic-scale and diurnal, contribute jointly to the strongest LLJs.

While the structure and dynamics of various manifestations of the LLJ over the Great Plains have been studied extensively, particularly during quiescent conditions, we know almost nothing about the structure and dynamics of the LLJ over the Gulf of Mexico or south of the Mexican border, where the topography differs considerably from that of the Great Plains. Observational studies by Bonner (1968), Djurić and Damiani (1980), and Djurić and Ladwig (1983) show the presence of secondary speed maxima at or near Brownsville, but the studies did not include data south of that location. Engel (1991) studied LLJs in Nested Grid Model analyses during lee cyclogenesis and found that a speed maximum typically existed $200 \mathrm{~km}$ east of Brownsville. Helfand and Schubert (1995) examined the output of a 2-month run of the Goddard Earth Observing System atmospheric general circulation model and found a substantial nighttime maximum of LLJ frequency over northeast Mexico, west-southwest of Brownsville, during May and early June. Ghan et al. (1996) found no such LLJ frequency maximum near Brownsville in 2- 

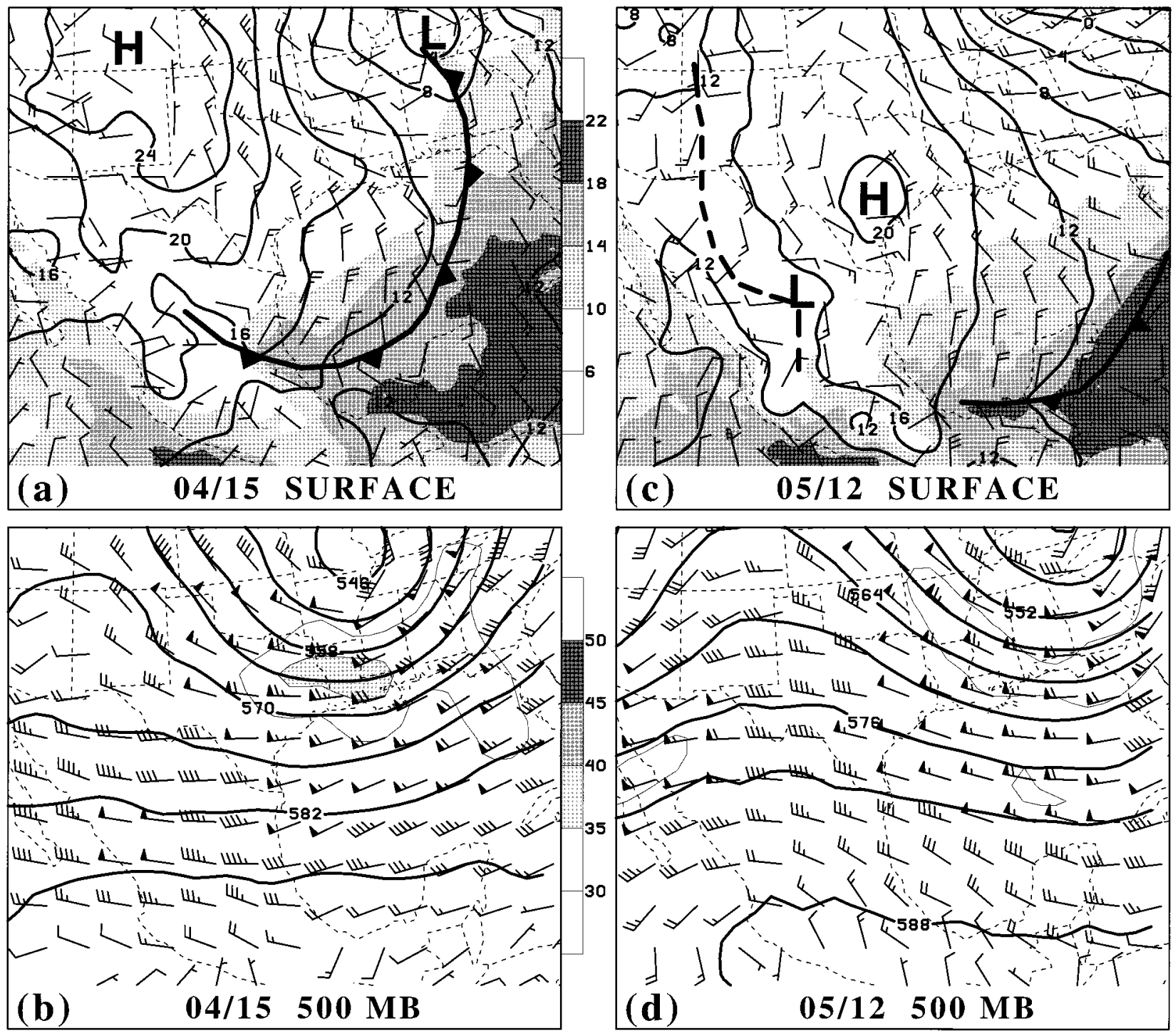

FIG. 2. Surface and 500-mb charts, 1500 UTC 4 April-1200 UTC 7 April. Surface charts: lowest model level winds $(1$ long barb $=5 \mathrm{~m}$ $\mathrm{s}^{-1}$ ), mixing ratio (shaded, $\mathrm{g} \mathrm{kg}^{-1}$ ), and pressure reduced to sea level (contoured, mb, leading digits dropped). The 500-mb charts: winds, wind speed (shaded, $\mathrm{m} \mathrm{s}^{-1}$ ), and geopotential height (contoured, decameters). The shading legend is located between the figure panels.

month runs of two other GCMs during June and July. The only direct evidence of southerly LLJ occurrence over the Gulf of Mexico may be the satellite observations of low-level cloud motions reported by Parmenter (1976), who found southerly speed maxima approaching $30 \mathrm{~m} \mathrm{~s}^{-1}$ extending northward from the Bay of Campeche.

This lack of knowledge of the structure and mechanisms of the southerly LLJ entering the continental United States makes it difficult to forecast the timing and location of the return of low-level moisture in advance of rain events or severe weather outbreaks. Poor performance by some operational models (Janish and Lyons 1992; Weiss 1992) and a lack of observations over Mex- ico and Gulf waters mean that even to nowcast LLJs south of the Mexican border is a challenging task.

The primary purpose of this paper is to determine the likely structure and kinematics of the LLJ over northeastern Mexico and the western Gulf of Mexico during the return flow cycle. Due to the sparseness of observations, we use a 3-day simulation of the return flow cycle by a mesoscale model to provide a high-resolution, dynamically consistent dataset representing a possible realization of return flow during an apparently typical event. To validate the LLJ dynamics of this simulation, we also examine the LLJs simulated over the southern Plains and compare them to previous observational and numerical studies. 

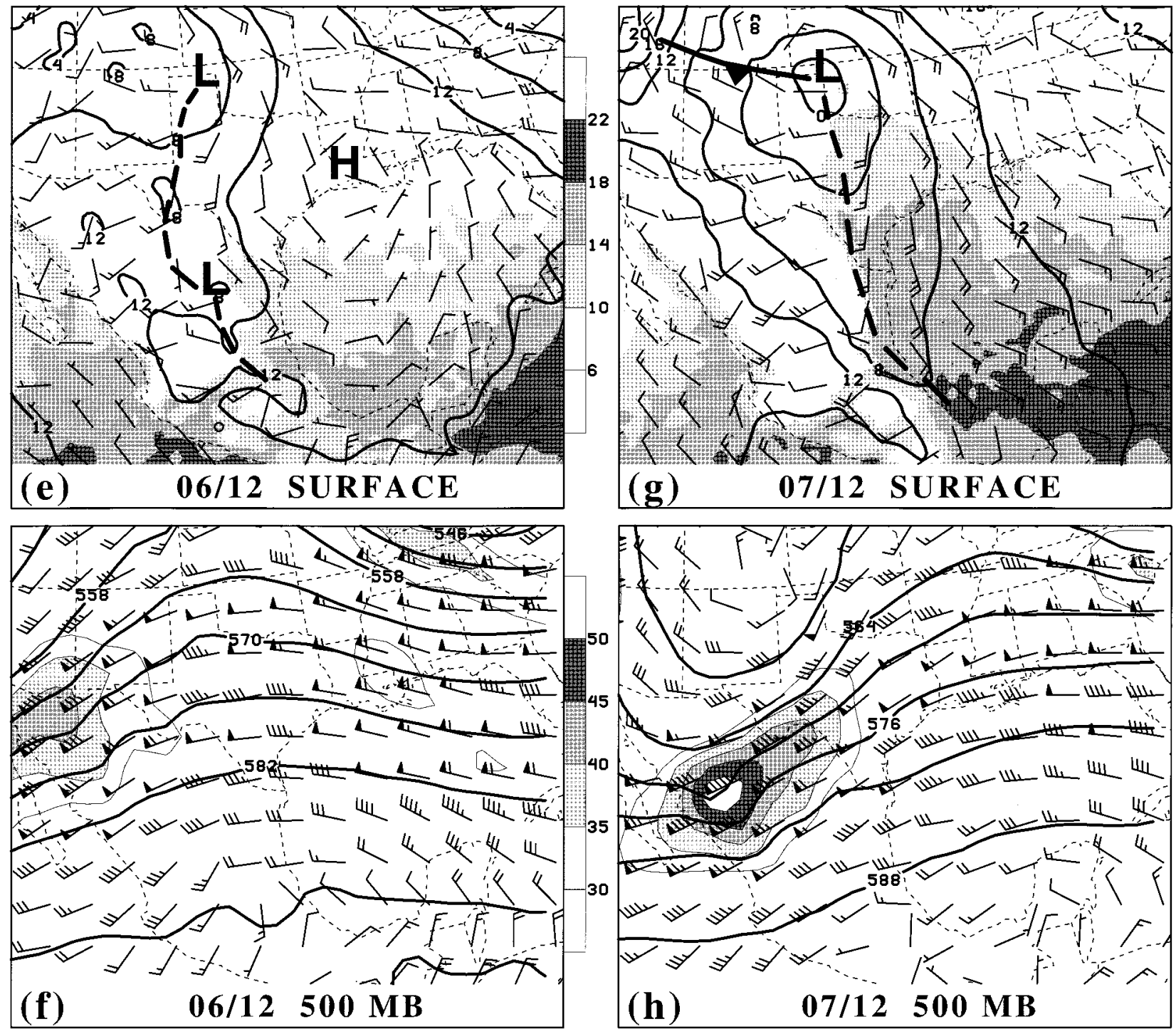

FIG. 2. (Continued)

A secondary objective of this paper is to provide a comprehensive overview of the LLJ evolution from southern Mexico to the central United States during a typical episode of return flow, and to show how the location and evolution of the LLJs are related to topography, surface heating, and synoptic-scale patterns. During a return flow cycle, the southern Plains and Gulf of Mexico LLJ environments often evolve from quiescent (beneath a 500-mb ridge, with weak midtropospheric westerlies) to active (with an approaching 500$\mathrm{mb}$ trough and intensifying midtropospheric westerlies). As we will show, mesoscale and boundary layer effects govern LLJ development during the quiescent period. As synoptic-scale processes become more important, the LLJ becomes structurally related to an intensifying lee trough and EML.

After describing the numerical simulation in section
2, we provide an overview of the synoptic-scale 500$\mathrm{mb}$ and surface features and a detailed analysis of the lee trough and EML development. These are followed by an overview of the LLJ development in time and space and a discussion of the mechanisms associated with the formation of each of the three southerly LLJ maxima that developed in the simulation. A discussion of the results and their implications concludes the paper.

\section{Model}

The model output used in this study is from a Penn State/NCAR (National Center for Atmospheric Research) Mesoscale Model, version 4 (MM4; Anthes et al. 1987), numerical experiment designed and conducted by Lanicci and Warner (1997). This model run used a high-resolution planetary boundary layer (Blackadar 
1979), and a horizontal diffusion scheme by Benjamin (1983). The horizontal diffusion coefficient was reduced to $20 \%$ of its normal value and the background value of the vertical diffusion coefficient was reduced from 1.0 to $0.1 \mathrm{~m}^{2} \mathrm{~s}^{-1}$, in order to help maintain small-scale structures that develop during the integration. The simulation uses a moist convective scheme (Kuo 1974; Anthes 1977), but this study is concerned only with the period prior to widespread convection.

The sea surface temperature (SST) pattern was obtained from 50-km SST analyses by the Marine Products Branch of the National Meteorological Center (now known as the National Centers for Environmental Prediction) for the period 5-10 April 1984. Studies by Zhang and Anthes (1982) and Lanicci et al. (1987) found that soil moisture availability has a large impact in the development of the planetary boundary layer. The standard MM4 land use categories were therefore subjectively blended with sets from previous severe storm modeling studies to obtain a set of categories tailored to the early spring rainfall climatology (Lanicci and Warner 1997). Satellite-based snow cover analyses were also used to identify regions of persistent snow cover during the time period of the model run.

A very large horizontal domain was used (Fig. 1) with $60-\mathrm{km}$ horizontal grid spacing and 30 sigma levels, half in the lowest $300 \mathrm{mb}$ providing very good resolution in the lowest levels of the model atmosphere. The model was initialized using archived $2.5^{\circ}$ lat $\times 2.5^{\circ}$ long surface and pressure-level analyses from the European Centre for Medium-Range Weather Forecasts (ECMWF), enhanced with surface and rawinsonde observations. Throughout the run, no data assimilation was employed and the lateral boundary points were updated every $12 \mathrm{~h}$ with ECMWF analyses. The model was initialized from data at 1200 UTC on 4 April 1984 (hereafter written as 04/12) and run for $120 \mathrm{~h}$, but only the output from the first $72 \mathrm{~h}$ (through 07/12) is discussed here.

The model run was tailored to study the development of low-level and boundary layer features. The high vertical resolution in the low levels of the model atmosphere, detailed land use categories and SST patterns, and the high-resolution boundary layer make this model run ideal to study the LLJ. The initiation of the model run during the offshore flow period allows the return flow LLJs to develop entirely through internal model dynamics, unaffected (for better or worse) by sparse, poorly distributed observations. Over land, this simulation successfully reproduced the low-level thermodynamic and kinematic structures observed during this return flow cycle despite timing errors of as much as $12 \mathrm{~h}$ in the synoptic-scale evolution (Lanicci and Warner 1997). See Lanicci and Warner (1997) and Lanicci (1991) for more information on the model characteristics and comparisons with observations.

\section{Synoptic overview}

At 04/15 in the MM4 run, a surface low was centered in Kentucky with an associated cold front trailing south into the central Gulf of Mexico (Fig. 2a). Behind the cold front, northerly and northwesterly flow was advecting dry air over the southern Plains and northwestern Gulf coast, while a northeasterly onshore flow prevailed along coastal sections of Mexico. Surface mixing ratio values in the southern Plains and northwest Gulf coast were below $6 \mathrm{~g} \mathrm{~kg}^{-1}$. The upper-level pattern (Fig. 2b) featured a 500-mb closed low along the Missouri-Illinois border with the upstream ridge axis located over Utah and Arizona. Various place names are shown in Fig 3.

Over the next $24 \mathrm{~h}$, a surface high pressure center moved into south Texas, setting up southerly flow in western sections of the state (Fig. 2c). The surface ridge axis extended south into extreme eastern Mexico maintaining a northeasterly flow along the Mexican coast in the form of a cold surge (Lanicci and Warner 1997; Tilley 1990). As dry air continued to flow into the Gulf, heat and moisture fluxes maintained the mixing ratio between 6 and $10 \mathrm{~g} \mathrm{~kg}^{-1}$ over the northwest Gulf, while values greater than $14 \mathrm{~g} \mathrm{~kg}^{-1}$ were present farther south with air which had resided longer in the marine boundary layer. The mixing ratio had increased in south Texas and eastern Mexico as moisture was transported northwestward on the western side of the ridge axis.

The surface high pressure center had moved into Louisiana by $06 / 12$, allowing for the southeasterly advection of Gulf moisture across the entire Texas coast (Fig. 2e). Lee cyclogenesis was occurring over southeastern Colorado, aiding the southerly flow and the transport of moisture into the Plains. Mixing ratios in excess of 10 $\mathrm{g} \mathrm{kg}^{-1}$ had returned to eastern Mexico, forming a dryline in the confluence region between the moist upslope flow from the east and the dry westerly flow from the Altiplanicie Mexicana (Mexican High Plain). By 06/21 (not shown), the dryline had developed northward into west Texas. Above the surface, the 500-mb ridge had moved over the central and southern Great Plains (Fig. 2f). A trough was located over California and Baja California with an associated jet streak extending northwest into eastern Mexico.

At 07/12, the surface low was located over the northeastern Texas panhandle and a lee trough was present over south Texas and northwestern Mexico (Fig. 2g). The moisture gradients associated with the dry line had strengthened across west Texas and eastern Mexico as the mixing ratio continued to increase within the moist southerly flow from the Gulf. Over the Gulf, tropical air from the Atlantic was now being incorporated into the return flow as shown by the westward movement of the $18 \mathrm{~g} \mathrm{~kg}^{-1}$ isohume into the Bay of Campeche. The $500 \mathrm{mb}$ trough had moved east and was centered over Colorado and New Mexico (Fig. 2h). A jet streak was 


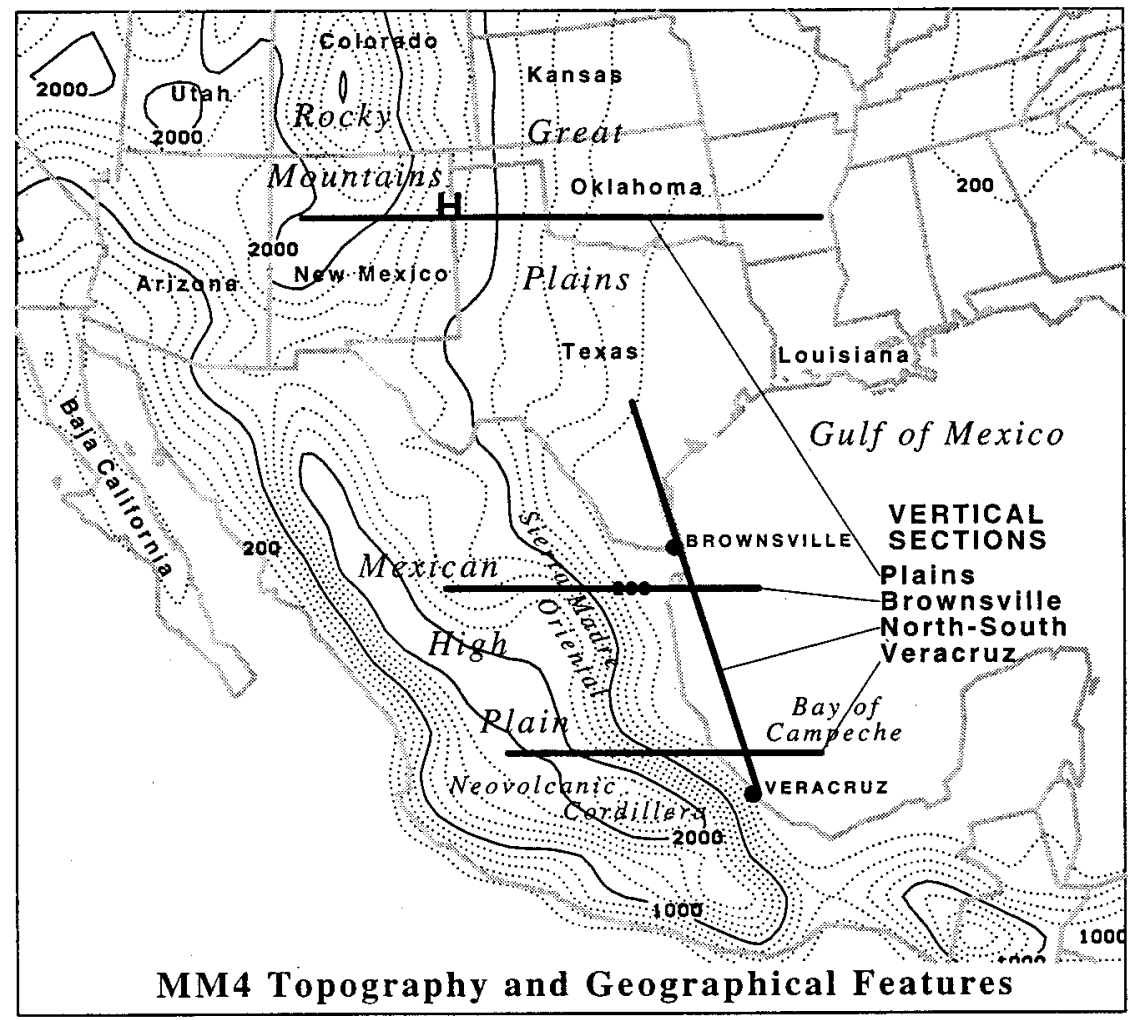

FIG. 3. Topographic height of the southern Plains and Mexico (contour interval: $200 \mathrm{~m}$ ), locations of places mentioned in the text, and locations of vertical sections. Note the difference in the slope of the terrain between the United States and Mexico.

located over northern Mexico and was entering southwest Texas.

\section{The lee trough and the elevated mixed layer}

As stated by Martin et al. (1995), the lee trough, the EML, and the LLJ over the central United States during the cool season have commonly been viewed as separate entities, even though they can share a common dependence on the interaction of westerly winds with topography. In this simulation, the processes that lead to the formation of the lee trough and EML over the southern Plains resemble those described by Carlson and Ludlam (1968) and Carlson et al. (1983) and modified by Martin et al. (1995). This section provides a more detailed look at the development and behavior of the lee trough and the EML over three diurnal cycles prior to and during the passage of an upper-level disturbance, including the evolution of these features over Mexico. The relationship of the LLJs to the lee trough and EML is discussed in later sections. The history of air parcels that constitute the EML in this simulation is documented in Lanicci and Warner (1997).

Figure 3 shows a portion of the topography used in the model and the location of vertical sections and geographic regions referred to in later discussions. The terrain varies north to south from the gently sloping plains of the southern United States to the steeply sloping Sierra Madre Oriental, which forms the eastern edge of the Mexican High Plain. The southern end of the Mexican High Plain is delineated by a line of volcanic mountains known as the Neovolcanic Cordillera. In this simulation, the meridional variations in the cross-barrier flow, topography, and surface characteristics govern the development and position of the lee trough over the southern Plains and the western Gulf of Mexico. These factors were shown by Benjamin (1986) to influence the location and strength of lee trough development in 2D model simulations.

Solar heating during the first day of the simulation generated a deep well-mixed layer of air with an associated region of low pressure over the elevated terrain of the southern Rocky Mountains and the Mexican High Plain. For the first $18 \mathrm{~h}$ of the simulation, wind speeds below $600 \mathrm{mb}$ over the elevated terrain were generally less than $5 \mathrm{~m} \mathrm{~s}^{-1}$, limiting the eastward advection of the mixed layer and helping to keep the sea level pressure trough collocated with the highest terrain (not shown). The upper-level ridge axis moved east of the highest terrain by $05 / 12$ and southwesterly winds increased to $12-15 \mathrm{~m} \mathrm{~s}^{-1}$ between 600 and $700 \mathrm{mb}$ over the southern Rocky Mountains. This allowed for some northeastward advection of the upper region of the 

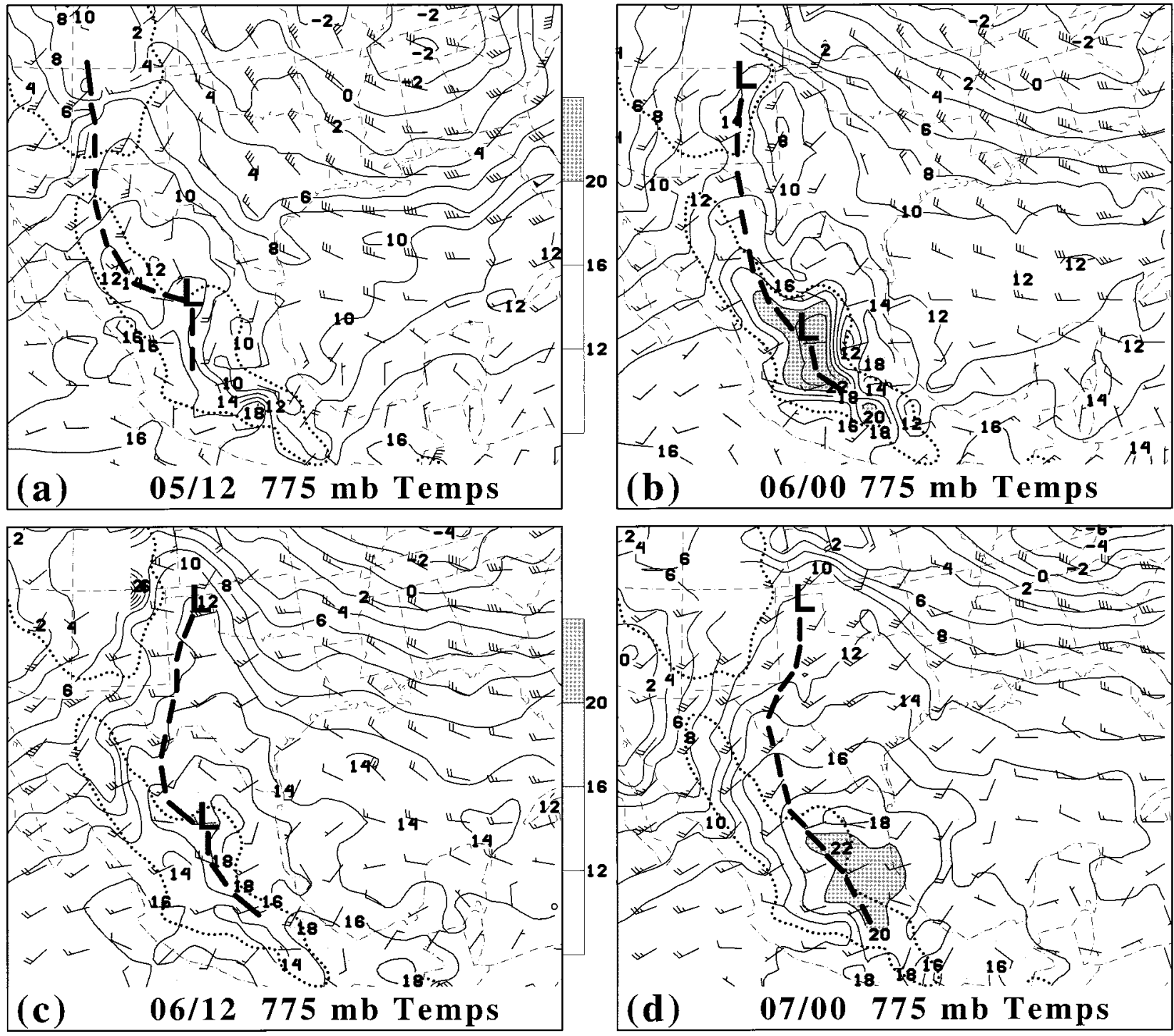

FIG. 4. Evolution of 775-mb temperatures (shaded, Celsius) and winds, 1200 UTC 5 April-0000 UTC 7 April, showing diurnal heating of air over the Mexican High Plain and Rocky Mountains and subsequent advection eastward. The locations of sea level pressure troughs and low centers are indicated by thick dashed lines and the letter "L."

mixed layer, but the sea level pressure trough remained over the highest topography (Fig. 4a). Winds remained weak over the Mexican High Plain during the period allowing a thermal low to form over a region classified as a "desert" in the model. The high altitude and low soil moisture values helped produce the highest potential temperature $(319 \mathrm{~K})$ over that area.

Daytime heating during the second day of the simulation continued to enhance the mixed layer over the elevated terrain of the southwestern United States and Mexico, while surface potential temperatures reached the highest values of the simulation. Over New Mexico, winds became more westerly and transported the upper regions of the daytime mixed layer eastward to form an EML over the Texas panhandle. By 06/12, winds over elevated terrain of New Mexico had become westerly near $15 \mathrm{~m} \mathrm{~s}^{-1}$ at all levels between the surface and 650 $\mathrm{mb}$. The entire mixed layer was thereby advected downward off the high terrain and onto the lower plains, and the lowest surface pressures (the lee trough) were found where the mixed layer was warmest and deepest (Figs. 4b,c and 5a) (Benjamin 1986). Since there was little directional and speed shear, the axis of maximum potential temperature remained nearly vertical over the lee trough. The warm air that had advected off the high terrain earlier in the day continued to overrun potentially cooler air over the eastern Texas panhandle and Oklahoma. This created the strong east-west temperature gradient in the layer between 750 and $850 \mathrm{mb}$ over the region. 

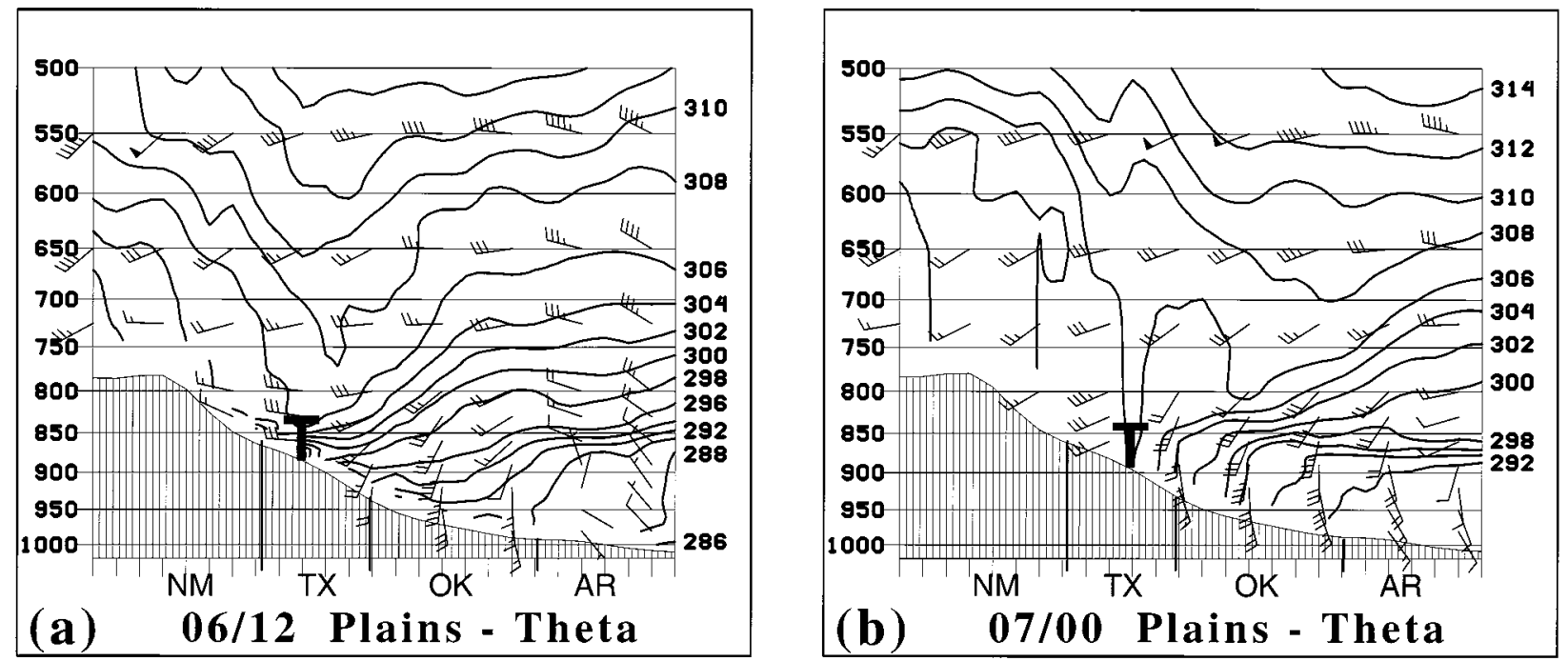

FIG. 5. Potential temperature $(\mathrm{K})$ and horizontal winds along the Plains vertical section (see Fig. 3 for location). Wind direction is indicated by orientation of barbs, with north being toward the top of the page. The " $\mathrm{T}$ " shows the location of the surface trough. The trough is beneath a deep layer of warm, weakly stratified air with a recent history of being heated over the high terrain to the west.

Farther south over Mexico the westerly winds were weaker than over the southern Rockies. The surface trough and thermal low were not displaced far eastward onto lower terrain and by 06/12, the thermal low was located on the eastern slope of the Sierra Madre Oriental with a shallow EML to its east (Figs. 4c and 6a).

The surface trough/lee trough that formed over the southern Plains and northern Mexico represented a confluence zone between moist southerly winds to the east of the trough and dry westerly winds on the west side of the trough. As the moisture gradients along the trough increased, it also became a dryline (Schaefer 1974). The strong moisture gradient first formed along the trough over the Mexican High Plain between 05/12 and 06/00 and later intensified over the southern Plains of the United States as moisture was advected northward on the east side of the trough (Fig. 2).

The northern and southern regions of the dryline behaved differently. The dryline over the Texas panhandle between 06/12 and 07/00 behaved "classically," moving eastward during the daytime hours (Schaefer 1974). Meanwhile, along the edge the Mexican High Plain, the dryline moved little during the daytime periods of 05/ $12-06 / 00$ and 06/12-07/00. Daytime heating over the region induced a thermally direct circulation over the eastern Sierra Madre Oriental, increasing the upslope flow. The signature of this upslope flow may be seen in the development of a sea-breeze-like temperature pattern between 06/12 and 07/00 (Figs. 6a,b). The convergence between the dry westerly flow near the top of the High Plain and moist upslope flow created and maintained a moisture gradient. The upslope flow induced during the daytime, together with the relatively weak westerlies across the High Plain, helped the trough remain stationary or even move westward in some areas.
In the two-dimensional simulations of Ookouchi et al. (1984), the heating along the steep slope was the primary driver of the circulation, with relatively dry soil conditions over the plateau (such as are found in the present simulation) also contributing weakly to upslope flow. In our simulation, widespread cloudiness within the coastal moist layer, commonly observed during return flow events, also contributed to the strength of the "inland sea breeze" (Yan and Anthes 1988).

By 07/00, an upper-level trough was approaching from the west. With cooler air aloft over the higher terrain, the highest surface potential temperatures continued to be collocated with the surface pressure trough. Meanwhile, the mixed layer from the previous day continued to progress east and northeastward and was evident as a tongue of warm air at $750 \mathrm{mb}$ extending northeastward from south Texas into Oklahoma (Fig. $4 d)$. Figure $5 \mathrm{~b}$ illustrates the continued eastward expansion of the EML over Oklahoma and Arkansas. Other studies (Carlson et al. 1983; Arritt et al. 1992) have documented similar mixed-layer configurations, with the base of the EML rising and the depth of the EML decreasing toward the east.

Between 07/00 and 07/12 dramatic changes took place over Mexico and the extreme southern Plains. A jet streak entered the region from the southwest and increased the wind speeds over the Mexican High Plain (Figs. 6b,c). The resulting downslope winds on the eastern slope were part of a large mountain wave which formed in the simulation over most of eastern Mexico (not shown). The warm air subsided as it was transported eastward, leading to a lee trough near the Gulf coast of Mexico that was contiguous with the preexisting lee trough in the southern United States and was entirely east of the elevated terrain (see Fig. 2h). 

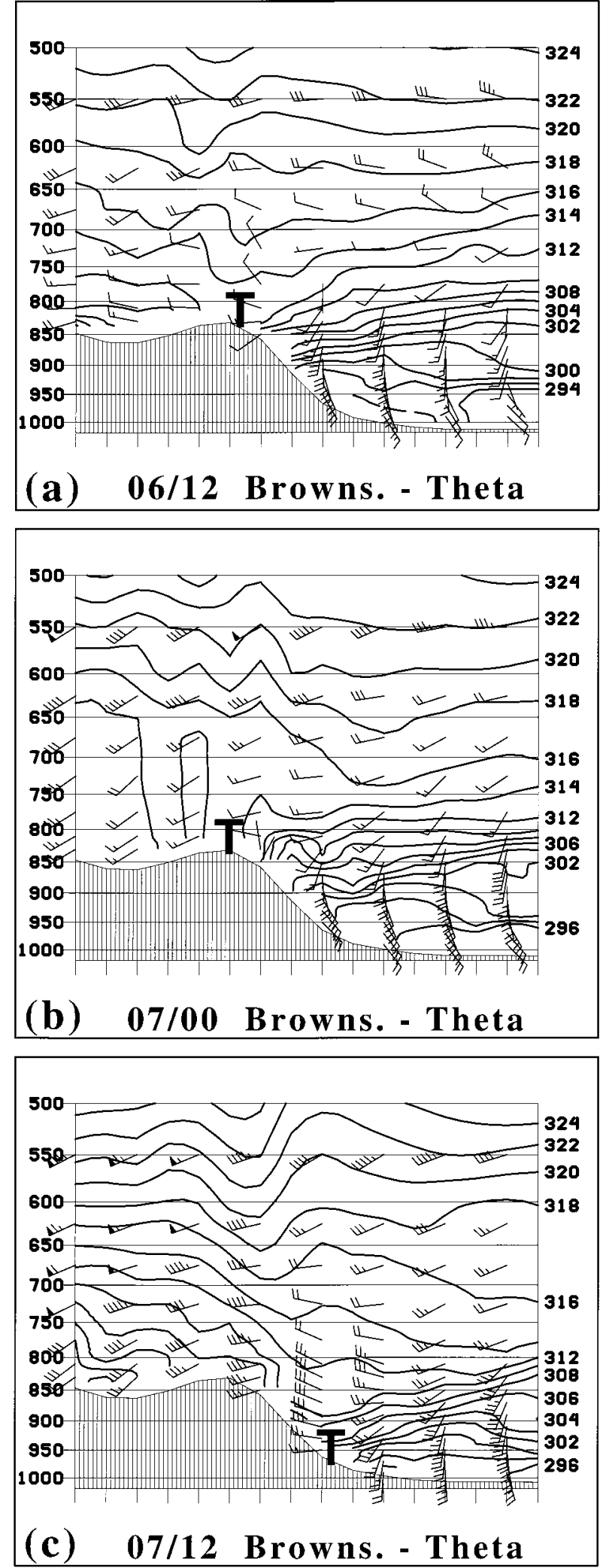

FIG. 6. Potential temperature $(\mathrm{K})$ and horizontal winds, Brownsville vertical section (see Fig. 3 for location). Note the migration of the cooler air up the slope with a structure resembling a sea breeze at 07/00, prior to the onset of strong westerlies over the High Plain.
In response to the approaching upper-level trough, a surface cyclone was intensifying as it moved southeastward into Texas and Oklahoma by 07/12. The frontal structure of this cyclone was nonclassical and closely resembled the central United States conceptual model of Martin et al. (1995) and Hobbs et al. (1996) with a surface trough extending southward from a surface low pressure center and a cold front extending westward into New Mexico. The development of the lee trough and the EML in this simulation is also similar to the conceptual model.

\section{Overview of simulated low-level jet evolution}

Low-level jets have been defined using a variety of criteria (i.e., Bonner 1968; Blackadar 1957). Most require the low-level wind maximum to reach at least 12 $\mathrm{m} \mathrm{s}^{-1}$, and then decrease upward to at most half of the maximum below a height of $3 \mathrm{~km}$. In this study, we define a LLJ as any grid-relative $v$ component (almost true north-south component) that exceeds $12 \mathrm{~m} \mathrm{~s}^{-1}$ and substantially decreases upward. The total wind speed was not required to decrease to one-half of its value in the lowest $3 \mathrm{~km}$ as in the other studies, but in most situations, this condition was exceeded or nearly met. In this simulation, low-level wind speed maxima formed in three distinct geographical locations. These jets will be referred to as the Plains jet, the Brownsville jet, and the Veracruz jet. The evolution of these jets is depicted in this section by a sequence of constant pressure maps located near the level of maximum low-level wind.

The Plains jet formed during the first night of the simulation and was located along the New MexicoTexas border at 05/12. It was relatively weak that night, with an 850-mb wind speed between 12 and $15 \mathrm{~m} \mathrm{~s}^{-1}$ (Fig. 7a). During the following day the LLJ dissipated by $05 / 18$ (Fig. 7b), and reformed slightly east of its previous location by $06 / 00$ (Fig. 7c).

The Brownsville jet encompassed a much smaller area than the Plains jet and was located southwest of Brownsville, Texas, at 05/12 (Fig. 7a). The jet showed a small increase in $850-\mathrm{mb}$ wind speed at 05/18 (Fig. 7b), but decreased again by 06/00 (Fig. 7c). A small region of easterly winds in excess of $12 \mathrm{~m} \mathrm{~s}^{-1}$ was located over the region previously occupied by southerly winds.

The next $15 \mathrm{~h}$ saw a rapid intensification of the Plains jet. By 06/06 the Plains jet encompassed all of west Texas and was forming northward into southern Kansas (Fig. 7d). Over the next 9 h, the Plains jet moved eastward into central regions of Kansas, Oklahoma, and Texas as wind speeds reached a maximum in magnitude and areal coverage (Fig. 7e). The wind speeds in the jet were initially greatest at $850 \mathrm{mb}$, but as the jet moved eastward over lower terrain, the wind speed maximum lowered to near $900 \mathrm{mb}$. The regeneration of the Brownsville jet began around 06/03. It developed just east of its previous position and had its maximum wind speeds at $900 \mathrm{mb}$ as opposed to $850 \mathrm{mb}$ the night before. 

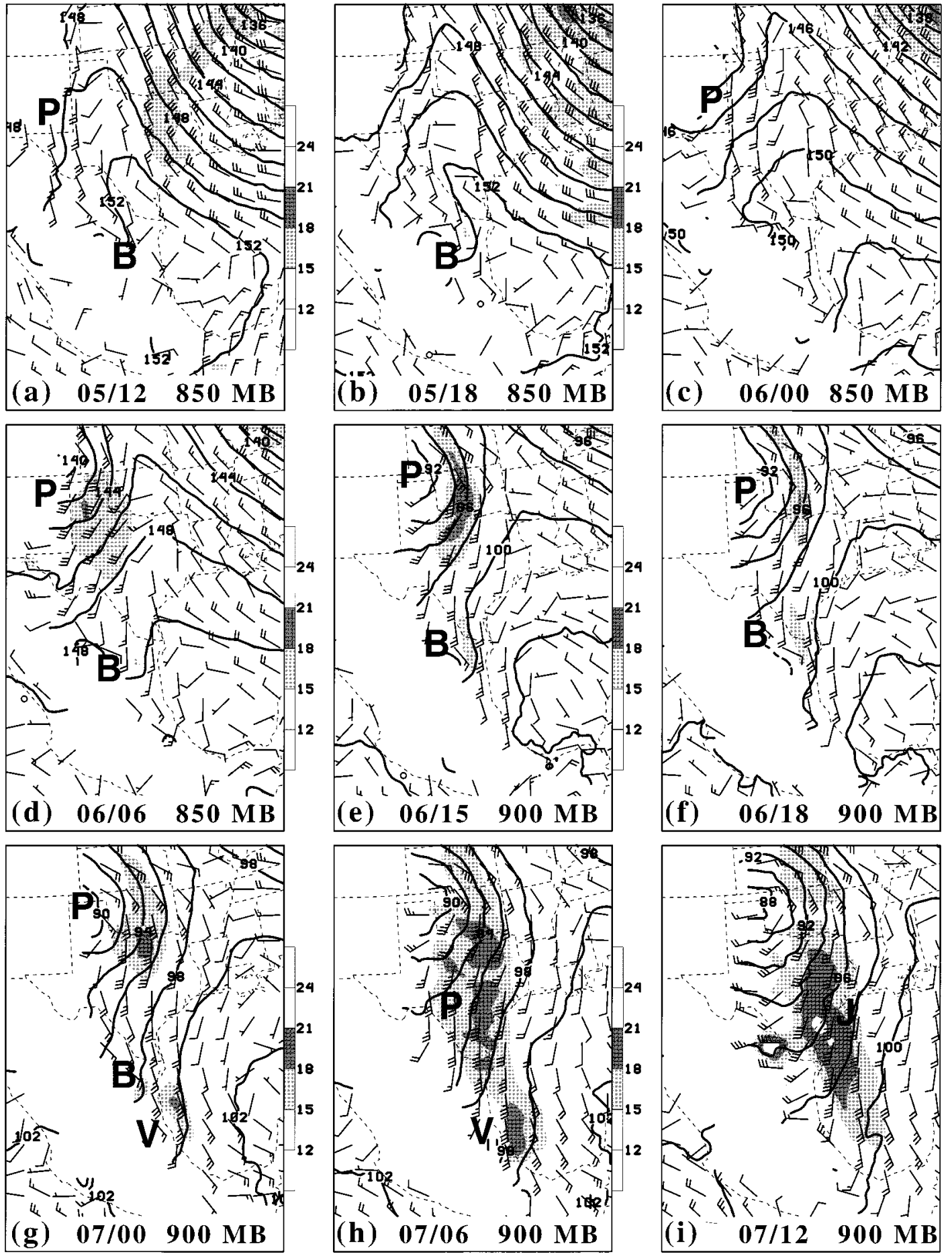

FIG. 7. Evolution of LLJs, 1200 UTC 5 April-1200 UTC 7 April. Winds and wind speeds (shaded, $\mathrm{m} \mathrm{s}^{-1}$ ) are shown at the approximate level of strongest low-level winds: $850 \mathrm{mb}$ through 0600 UTC 6 April; $900 \mathrm{mb}$ thereafter. Wind maxima are designated as the Plains jet ("P"), Brownsville jet ("B"), Veracruz jet ("V"), and unified jet ("J").

Wind speeds within the jet steadily increased, approaching $20 \mathrm{~m} \mathrm{~s}^{-1}$ near its southern end by 06/15 (Fig. 7e). The southern end of the jet remained nearly stationary while the wind speeds increased downstream toward southwest Texas, joining the southern part of the Plains jet in a region of wind speeds between 12 and $15 \mathrm{~m}$ $\mathrm{s}^{-1}$.

The wind speeds in the Plains jet decreased from 06/ 

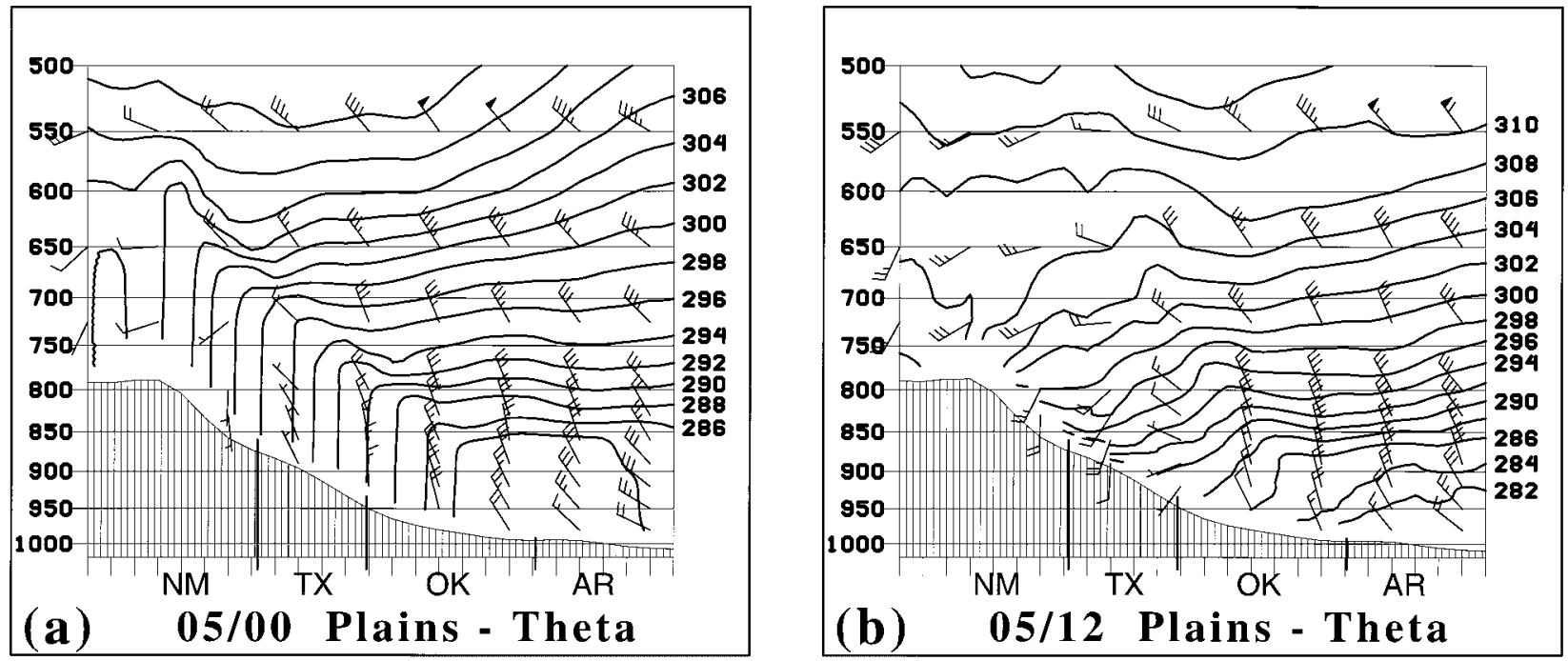

FIG. 8. Potential temperature (K) and horizontal winds, Plains vertical section. See text for discussion.

15 to $06 / 18$ (Fig. 7f), but increased again after 06/18. By $07 / 00$, the fastest $900-\mathrm{mb}$ wind associated with the Plains jet was near $20 \mathrm{~m} \mathrm{~s}^{-1}$ over north Texas (Fig. 7g). Over the next $6 \mathrm{~h}$, the Plains jet rapidly developed to the south and west, extending into south Texas where it was merging with the Brownsville and Veracruz jets (Fig. 7h).

The Brownsville jet began to decline after 06/15. At $06 / 18$, the maximum $900-\mathrm{mb}$ wind speed in the jet had decreased to below $18 \mathrm{~m} \mathrm{~s}^{-1}$, although the jet had extended downstream into Texas (Fig. 7f). The areal coverage of the jet decreased markedly by $07 / 00$ (Fig. $7 \mathrm{~g}$ ). All that remained of the jet at $900 \mathrm{mb}$ was a small region of winds greater than $15 \mathrm{~m} \mathrm{~s}^{-1}$ near the previous southern edge of the jet. By 07/06, a distinct signature of the Brownsville jet is no longer apparent on the $900-\mathrm{mb}$ chart (Fig. 7h), and vertical sections (not shown) suggest the jet has merged with the Veracruz jet.

The first hint of the developing Veracruz jet is in the southwest Gulf of Mexico at 06/15 (Fig. 7e). Over the next $9 \mathrm{~h}$, the Veracruz jet rapidly increased in intensity and areal coverage, encompassing the extreme western Gulf from north of Veracruz, Mexico, to Brownsville, Texas (Fig. 7g). By this time, the Veracruz jet was beginning to merge with the eastern portion of the Brownsville jet. The jet continued to increase in speed over the following $6 \mathrm{~h}$, as a region of 900-mb winds in excess of $18 \mathrm{~m} \mathrm{~s}^{-1}$ covered the western Bay of Campeche at 07/06 (Fig. 7h).

Over the final $6 \mathrm{~h}$, westerly winds developed near the border of Mexico and south Texas and extended south into coastal sections of eastern Mexico (Fig. 7i). These westerly winds were associated with the formation of a lee trough over the region, confining the southerly LLJ to areas east of the lee trough. This is most clearly evident over the southwestern Gulf where the southern region of the Veracruz jet had weakened considerably by $07 / 12$. By this time, only one large southerly LLJ system existed. There was, however, a separate southeasterly low-level wind maximum over regions of northern Oklahoma and southern Kansas located near the surface warm front.

\section{The low-level jets}

The following subsections describe the mechanisms responsible for the formation of three LLJs described above. Each jet is unique in some aspect of its formation, but all are related in some way to the local topography.

\section{a. The Plains jet}

The jet which first formed over the sloping terrain of New Mexico and west Texas during the first night of the simulation closely resembled the well-documented summertime LLJs over the southern Plains (Zhong et al. 1996, and references therein). These LLJs are a consequence of the diurnally varying heating and friction over sloping terrain. The simulated evolution, described below, closely followed the sequence of events in the two-dimensional simulation by McNider and Pielke (1981).

The first step was the establishment of a baroclinic zone within the daytime mixed layer (Fig. 8a). Isentropes, initially nearly horizontal, became vertical within the mixed layer, and the low-level temperature gradient was further enhanced by the increasing depth of the mixed layer to the west due to the relative dryness of the underlying surface in the simulation. The vertical geostrophic wind shear implied by the horizontal temperature gradient was prevented from being realized by the vertical mixing taking place within the boundary layer.

At night, a low-level radiative inversion formed (Fig. 
Time Hodograph

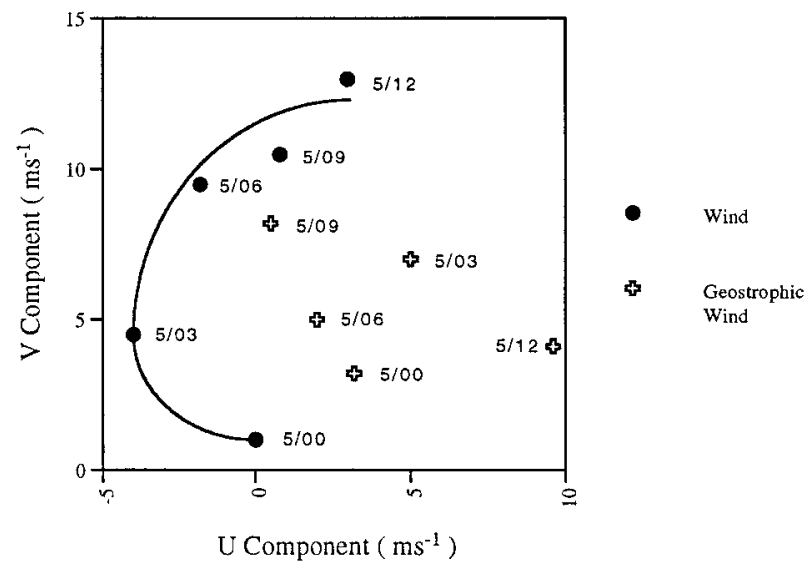

FIG. 9. Hodograph showing apparent inertial oscillation of the vector horizontal wind during the night of 4-5 April at a point in the Texas panhandle (point " $\mathrm{H}$ " in Fig. 3).

$8 b)$ and convective mixing ceased. This decoupled the old boundary layer from the surface, allowing an inertial oscillation to occur (Blackadar 1957). The oscillation was strongest near the base of the old boundary layer, where the winds were most strongly subgeostrophic. An 830-mb time hodograph (Fig. 9), constructed at a point where the oscillation was largest (point $\mathrm{H}$ in Fig. 3), displays the characteristic turning with time of a slightly damped inertial oscillation, with the wind vector executing a near-semicircle about the geostrophic wind vector between $05 / 00$ and $05 / 12$. The geostrophic wind, while erratic, shows no evidence of the nighttime weakening of the $\nu$ component that would be expected if the Holton (1967) mechanism for quiescent LLJ formation were operating.

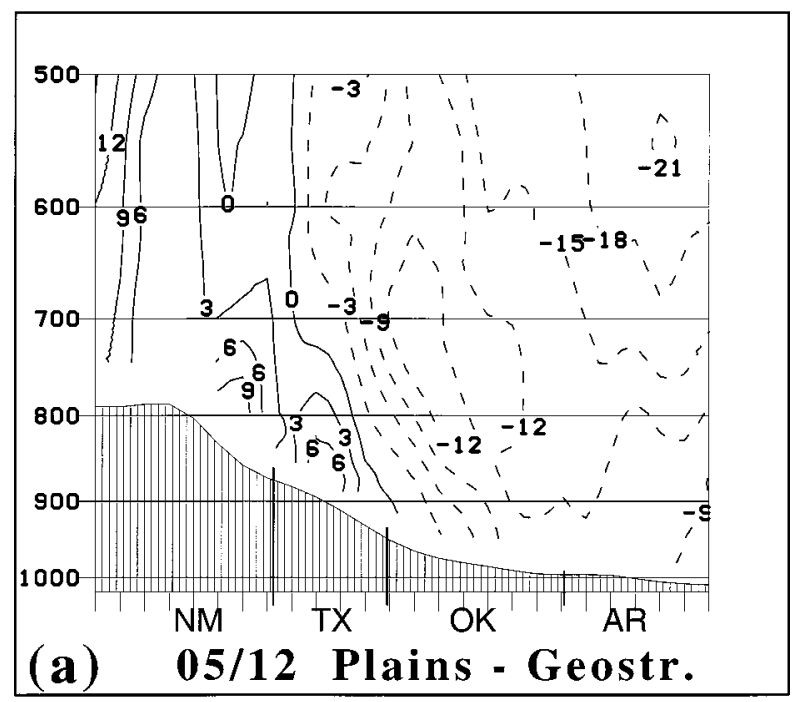

Figure 10 shows the north-south components of geostrophic and total wind. Through most of the cross section, there is northerly geostrophic shear, such that the strongest southerly geostrophic winds were located near the surface, just above the nocturnal inversion, which had caused a reversal of the temperature gradient immediately adjacent to the ground. The total southerly wind was also largest just above the nocturnal inversion and was strongly supergeostrophic.

This LLJ dissipated during the following day, as heating again produced a well-mixed boundary layer, but reformed the following night. To varying extents, other inertial oscillations were found during other nights over the Plains and elsewhere, but the first night's LLJ was the purest example of an inertial oscillation LLJ during the simulation.

The jet which formed over the Plains the following night began as an inertial oscillation and was later influenced by the pressure gradient associated with the formation of an elevated mixed layer. At 06/06, the jet was supergeostrophic and formed a shallow ribbon several hundred kilometers wide along the top of the nocturnal inversion (Fig. 11a). However, in response to the large-scale flow and the developing cyclone, winds had become westerly over New Mexico at all levels, and the westerlies at $700 \mathrm{mb}$ over the Texas panhandle indicate the advection of mixed-layer air eastward over the Plains and the formation of an EML. By 06/12 (Fig. 11b), the lee trough had progressed to Texas, and a strong lowlevel horizontal temperature gradient had been established within the stable layer beneath the EML to the east of the surface trough. The LLJ was now a stronger, more localized core of southerlies. While the wind speeds had increased slightly, the geostrophic winds had increased substantially, so that the LLJ was no longer

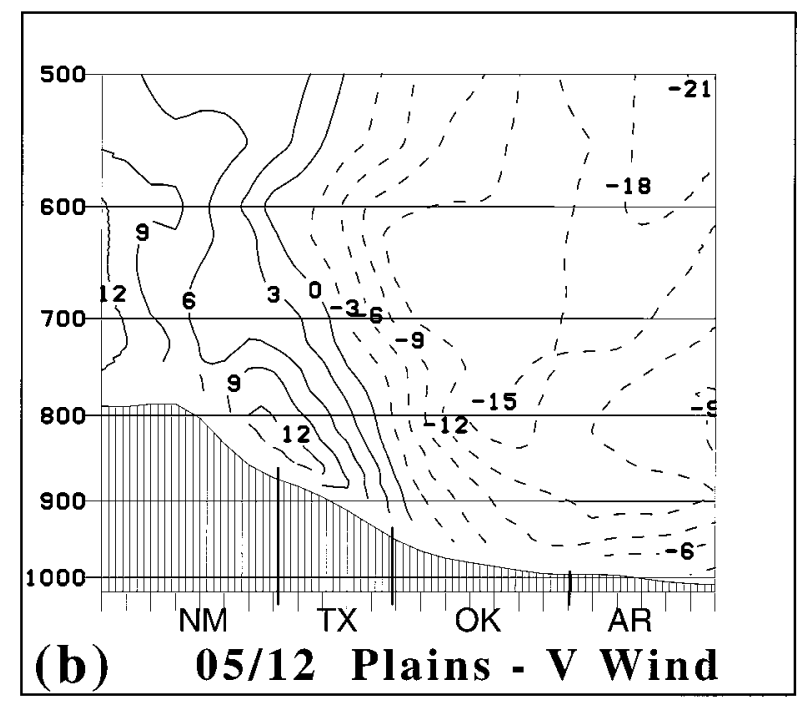

FIG. 10. The $y$ component $\left(\mathrm{m} \mathrm{s}^{-1}\right.$ ) of (a) geostrophic wind and (b) full wind along the Plains vertical section, showing supergeostrophic southerly jet above Plains at night. Solid (dashed) contours represent southerly (northerly) airflow. 

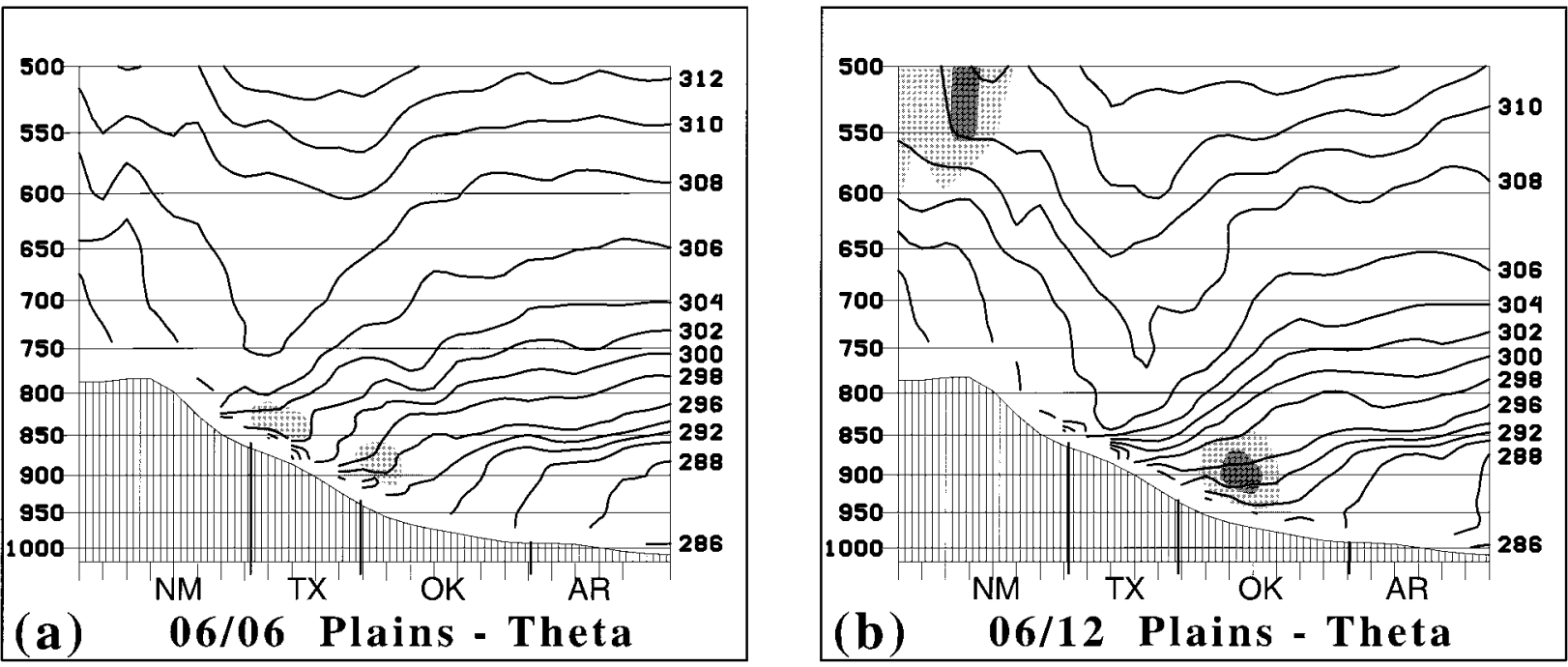

FIG. 11. Potential temperature (contours, K) and $y$ component of wind (shaded, increments at 12, 15, and $18 \mathrm{~m} \mathrm{~s}^{-1}$ ) along the Plains vertical section, showing evolution of the day 2 Plains jet from a broad inertial oscillation type jet to a deeper, balanced EML type jet. The $\mathrm{V}$ shape in the isentropic surfaces represents the warm pool of air that was heated over the elevated terrain to the west during the previous day. This air descends down the slope and overruns the potentially cooler air to the east forming an EML.

supergeostrophic. Note that this pressure variation is exactly opposite what would occur in quiescent conditions over sloping terrain (Holton 1967).

Early in the night, the jet was located at the top of the nocturnal inversion. As the EML developed, the temperature gradient associated with the sloping EML inversion implied a strong low-level pressure gradient to the east over Oklahoma. The shape and position of the LLJ were influenced by this evolution. With the temperature gradient primarily above $850 \mathrm{mb}$ and the strongest horizontal pressure gradient extending from $850 \mathrm{mb}$ downward, the LLJ increased in depth as it moved eastward over lower terrain.

The advection of the warm air from the elevated terrain to the west provided a mechanism to maintain and expand the temperature gradient over the Plains, thereby reinforcing the pressure gradient responsible for the LLJ. The LLJ remained under the sloping EML inversion during the third day but increased in speed and areal coverage. The region was also apparently influenced by the pressure falls associated with the approaching upper-level trough. Prior to the trough moving into the southwestern United States, the LLJ was strongest in the early morning and weakest in the afternoon. The increase in speed and areal coverage during the afternoon suggests the evolving synoptic-scale pressure field was overriding the diurnal mechanisms in accelerating the LLJ (Djurić and Damiani 1980). It is also apparent from Figs. 7 and 11 that while synoptically forced ageostrophic winds may have contributed to the jet strength, the Plains jet during 6 and 7 April was predominantly in geostrophic balance with the low-level pressure gradient.

\section{b. The Brownsville jet}

The Plains jet initially took the form of the frequently studied inertial oscillation of the southerly wind in the presence of northerly geostrophic shear, but later came more into geostrophic balance (and less subject to diurnal variations) as a strong pressure gradient developed beneath the EML ahead of the developing lee trough and cyclone. Farther south, where the topography rises abruptly to the Mexican High Plain, no inertial oscillation of the Plains type was found. Instead, the Brownsville jet throughout its simulated existence was most directly related to the pressure gradient beneath the EML.

The sequence of events during the development of the EML (discussed in broad terms in section 4) resembled the low-resolution simulation by Benjamin (1986) and the two-dimensional simulation of Arritt et al. (1992). The necessary ingredients are an elevated plateau (in this case, the Mexican High Plain) for a heat source and a cross-mountain flow to advect the heated air downstream. With southwesterly cross-mountain flow, the Mexican High Plain is widest southwest of Brownsville (Fig. 3), and is classified as "desert" in the model. The highest temperatures above the Mexican High Plain prior to the arrival of cooler air from the west were consequently found southwest of Brownsville, near the Sierra Madre Oriental (Figs. 4b,c). The resulting EML inversion and (through hydrostatic balance) low-level pressure gradient were strongest between Brownsville and the edge of the Mexican High Plain, apparently leading to the simulated LLJ maximum there. This section will focus on the evolution of the EML inversion, the low-level pressure gradient, and the 
Brownsville jet during the second afternoon and night of the simulation.

At 05/21 (Fig. 12a), a strong temperature gradient had formed along the edge of the High Plain. To the west is a 125 -mb-deep mixed layer formed by surface heating over the dry High Plain. To the east the air was cooler, due both to its source over the Gulf of Mexico and the weaker sensible heating over the coastal plain. In the simulation, a direct circulation was established, like an inland sea breeze (Ookouchi et al. 1984; Yan and Anthes 1988), with the low-level cooler air moving upslope toward the heated plateau. A strong inversion was produced above the "sea breeze," overlain by mixed-layer air which had been transported off the High Plain and over the cooler air, where it weakly subsided. A similar structure formed again on the following day (Fig. 6b).

During the night, the direct circulation dissipated, and the strong temperature gradient migrated partway down the Sierra Madre Oriental in the presence of westerlies at the top of the mountains (Fig. 12b). The inversion underlying the plateau air became sloped upward toward the east, and the mixed layer air (between $312 \mathrm{~K}$ and $316 \mathrm{~K}$ ) formed a wedge above it, deepest at the plateau edge and shallower toward the east. In the simulation of Arritt et al. (1992), the wedge remains neutrally stratified, but it appears that vertical mixing was strong enough in this simulation to cause weak stratification.

Unlike the quiescent Plains jet, the Brownsville jet (Fig. 13b) was centered at the base of an inversion. In Fig. 12b, two inversions are present: the inversion (294$298 \mathrm{~K}$ ) atop the marine atmospheric boundary layer, which is weaker over land, and the inversion (302-308 $\mathrm{K})$ at the base of the EML, which weakens to the east. The jet is in approximate geostrophic balance with the vertically varying pressure gradient associated with the sloping EML inversion (Figs. 12 and 13), and therefore is found at the base of this inversion. Beneath the jet, the low-level upslope flow tilts the marine boundary layer inversion and produces a reversal of the temperature gradient and thermal wind near the ground, reducing the pressure gradient there.

The three-dimensional structure of the resulting LLJ involves a complicated interplay between the slope of the EML inversion and the acceleration and convergence of air parcels beneath the EML inversion. The low-level air accelerated as it entered the area of the strong pressure gradient. The Lagrangian inertial oscillation experienced by air parcels (not shown) produced maximum wind speeds near and downstream of the strongest pressure gradient (Figs. 14a,b).

As noted in section 5, the Brownsville jet peaked in intensity during the morning hours and weakened during the afternoon. The low-level pressure gradient underwent similar diurnal variations (Fig. 7). This cycle is related to the strength and orientation of the EML inversion. The inversion tilts upward toward the High Plain (Fig. 12a) during the afternoon as the upslope flow becomes established. During the evening the inversion strengthens as the hot air from the High Plain moves northeastward over the cooler air along the slope. At night, the downslope flow carries the Mexican High Plain air partway down the slope, causing the EML inversion to tilt upward away from the High Plain. This maximizes both the strength of the horizontal temperature gradient and the strength of the pressure gradient beneath it.

\section{c. The Veracruz jet}

During the third day of the simulation, a low-level feature that we call the Veracruz Jet developed rapidly over the western Gulf of Mexico. Near Veracruz, the Neovolcanic Cordillera protrudes eastward, forming a barrier to southeast-northwest flow (Fig. 3). We hypothesize that the jet forms in response to the low-level airflow being blocked by, and accelerating around, the topography.

The jet formed during the morning of 6 April to the northeast of this obstacle (Fig. 7e). During the day, the jet rapidly intensified as it expanded northward over open waters. By 07/00, the jet encompassed the extreme western Gulf of Mexico and was merging with the Brownsville jet (Fig. 7g). The rapid intensification appears to be related to an increase in the speed of the larger-scale southerly airflow impinging upon the topography (Figs. 7d,h). In addition, westerly winds above the Neovolcanic Cordillera were beginning to transport well-mixed air from the elevated terrain to the west forming an EML over the region (Fig. 15).

The fastest winds were located just downstream of the barrier where the pressure gradient was the strongest. An important feature of this jet is its proximity to the ocean surface. Maximum speeds at 07/00 were near 19 $\mathrm{m} \mathrm{s}^{-1}$ near $950 \mathrm{mb}$. Since the temperature gradient does not reverse sign near the surface, a northerly thermal wind is present throughout the low levels. Farther downstream of the barrier, the pressure gradient and wind speed were weaker, and the jet sloped upward following isentropic surfaces (Fig. 16)

During the next few hours the wind speeds continued to increase, approaching speeds near $22 \mathrm{~m} \mathrm{~s}^{-1}$ at 930 mb by $07 / 06$. Meanwhile, a small-scale eddy formed to the west of the jet in the lee of the obstacle (Fig. 17). This intensification was short lived, however, because by $07 / 12$, westerly winds had descended down the plateau and toward the southwestern Gulf, forming a welldefined lee trough over the region (Fig. 2g). Once the low-level southerlies had been displaced eastward and no longer impinged on the topography, the jet weakened dramatically (Fig. 7i).

The features found in this simulation are very similar to those in a modeling study by Eddington et al. (1992) of a persistent wind maximum observed near Point Conception, California. In their study, the low-level flow is forced around an elevated headland, smaller than but 

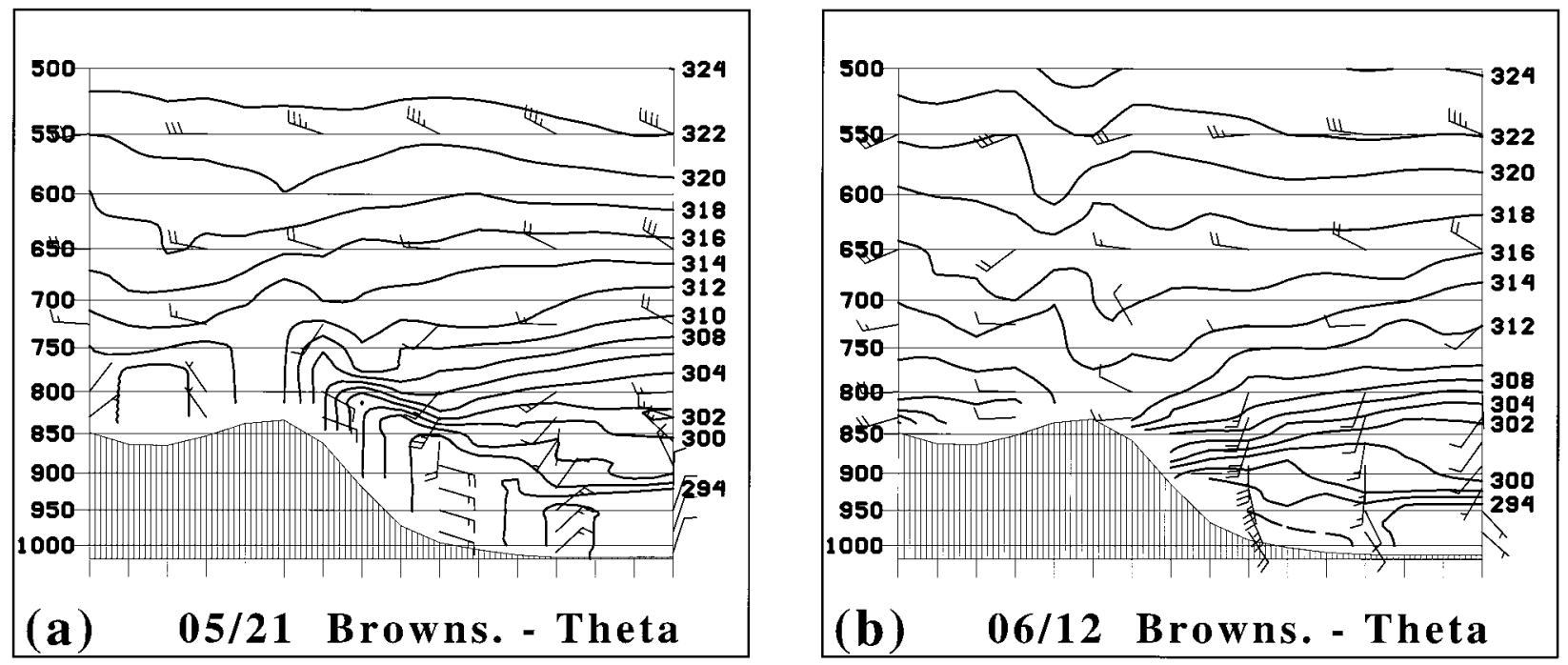

FIG. 12. Potential temperature $(\mathrm{K})$ and horizontal winds, Brownsville vertical section, showing the development of the EML and the associated sloping inversion east of the Mexican High Plain. The EML is located in Fig. 12b between the 312-K and 316-K isentropic surfaces just east of the High Plain. A wedgelike shape is evident as the EML decreases in depth toward the east.

similar in shape to the topographic feature near Veracruz. Near the headland, boundary layer heights were largest on the upwind side and smallest on the downwind side. This induces a pressure gradient downwind of the headland, causing the airstream to accelerate as it passes the obstacle. In both simulations the fastest winds are found near or at the surface. The Veracruz jet also bears resemblance to a wind maxima in the East African jet near Madagascar. Simulations by Bannon (1979) suggest that blocking of the airstream by the highlands of Madagascar is responsible for an acceleration in the airflow around the northern tip.

The degree to which flow is blocked by orography depends upon the Froude number $(\mathrm{Fr}=U / N h)$, where $U$ is the mean wind speed, $N$ is the buoyancy frequency, and $h$ is the obstacle height. Smolarkiewicz and Rotunno (1989) note that if the Froude number is less than 0.5, the flow will tend to be diverted around an obstacle instead of flowing over it. In this model simulation, the obstacle is approximately $2000 \mathrm{~m}$ high and the Froude number upstream at an altitude about half that of obstacle is approximately 0.3 , suggesting that the flow should be diverted around the topography. The similarities in topography and airflow patterns of the two wind maxima suggest that similar mechanisms were responsible for their creation.
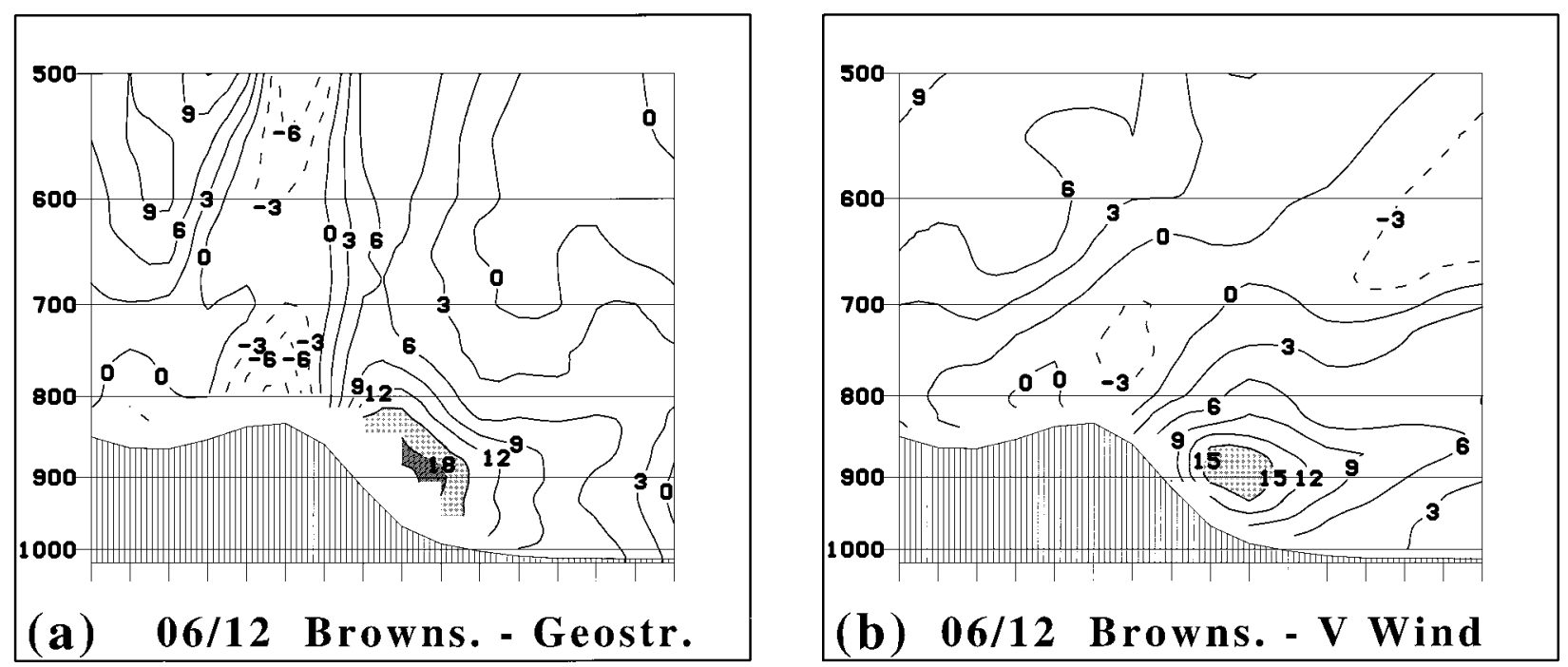

FIG. 13. The $y$ component $\left(\mathrm{m} \mathrm{s}^{-1}\right)$ of (a) geostrophic wind and (b) full wind, Brownsville vertical section. The jet is nearly in geostrophic balance and is situated at the base of the EML inversion (cf. Fig. 12b). 


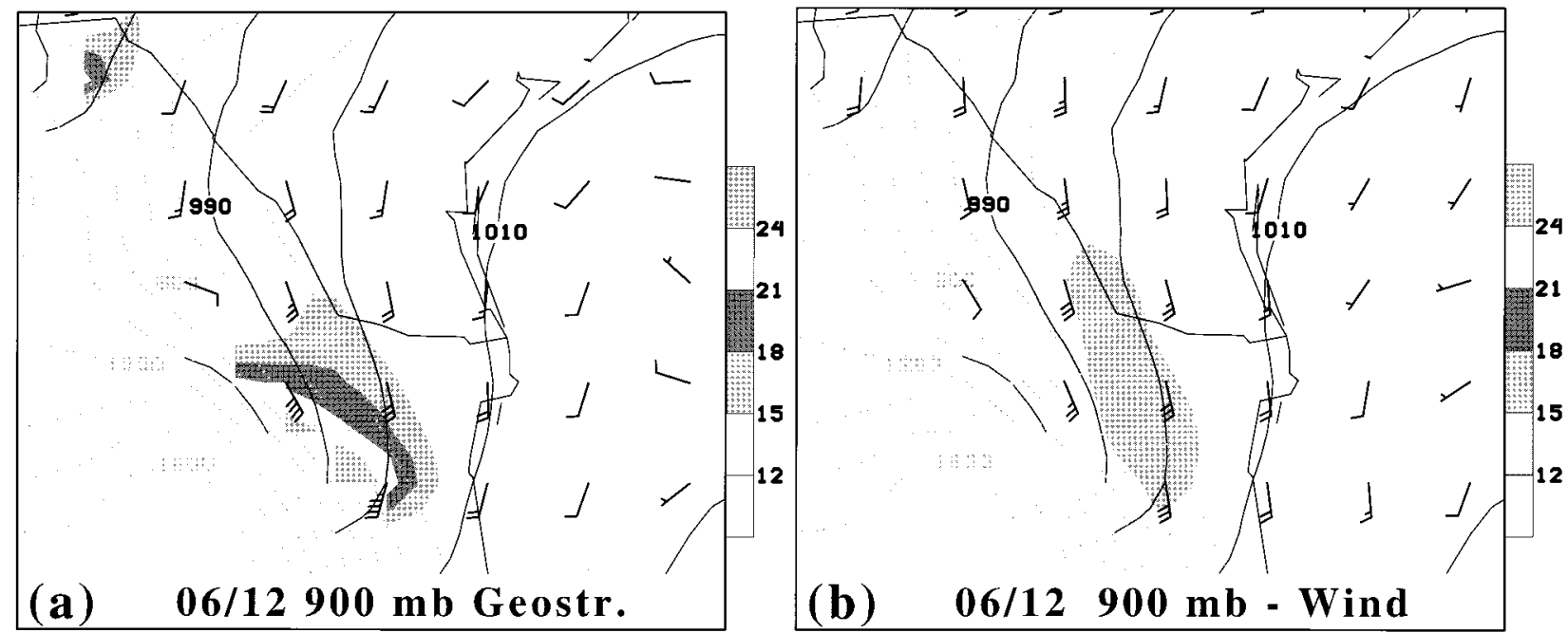

FIG. 14. The 900-mb (a) geostrophic and (b) full winds and wind speeds (shaded, $\mathrm{m} \mathrm{s}^{-1}$ ), Brownsville jet. Alternating grid points are shown for clarity. Supergeostrophic wind speeds are shown downstream from the region of the strongest pressure gradient.

\section{Discussion}

This model simulation of southerly LLJ formation is consistent with previous observational and theoretical work on the subject. The Plains jet evolution, particularly during the quiescent conditions of the first night, closely resembles the two-dimensional idealized simulation of McNider and Pielke (1981) and is similar in timing, structure, and geographical extent to other observational studies. The development of the EML, which directly affected the structure and intensity of the underlying LLJs, also resembled idealized high-reso-

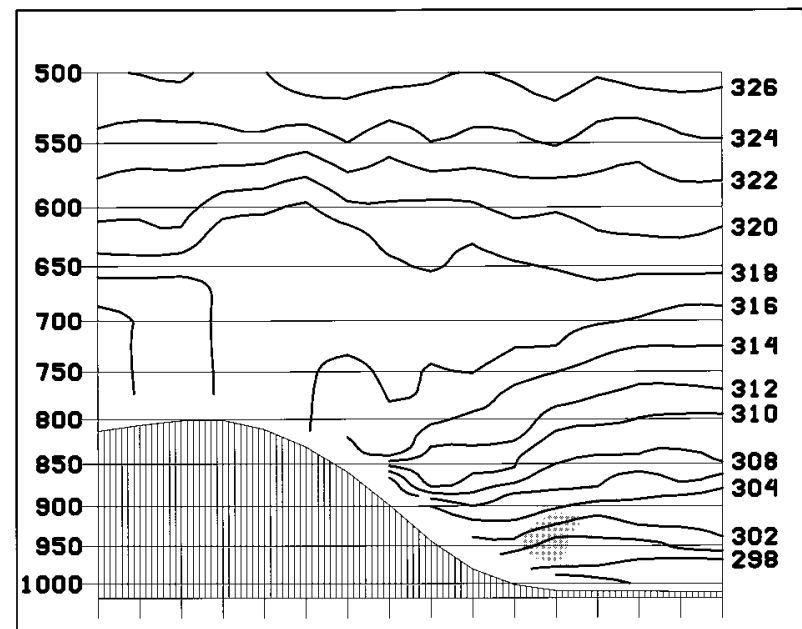

\section{7/00 Veracruz - V Wind}

FIG. 15. Potential temperature (contours, K) and $y$ component of wind (shaded, increments at 12 and $15 \mathrm{~m} \mathrm{~s}^{-1}$ ), Veracruz vertical section. The southeasterly airflow is blocked by the upstream topography (not shown here; see Fig. 3), causing the air to accelerate as it moves around the obstruction. An EML is evident between the $316-\mathrm{K}$ and $318-\mathrm{K}$ isentropic surfaces. lution two-dimensional simulations, such as those by Arritt et al. (1992). The model simulation corresponded fairly well to available observations of the event (Lanicci and Warner 1997). Finally, the evolution of the LLJs in time and space during this simulated return flow event resembled the composite cool-season LLJ evolution presented by Djurić and Damiani (1980) and Djurić and Ladwig (1983). Consequently, it seems reasonable to treat the structures and dynamics of this simulation as realistic representations of the actual evolution of the atmosphere during the return flow cycle.

This simulation suggests that, in addition to the wellknown Great Plains LLJ, there are additional low-level

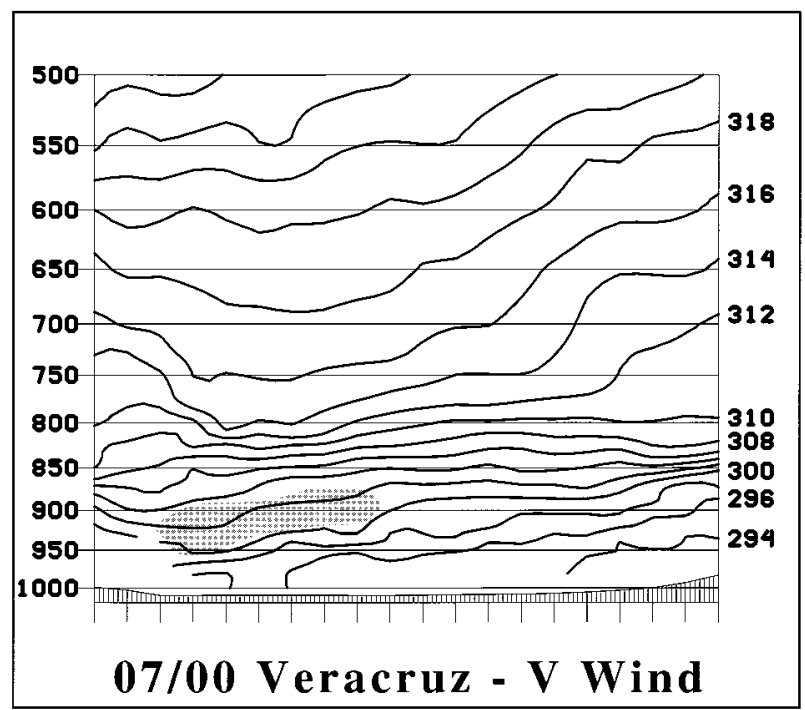

FIG. 16. Potential temperature (contours, K) and $y$ component of wind (shaded, increments at 12 and $15 \mathrm{~m} \mathrm{~s}^{-1}$ ), north-south vertical section. The airflow in the jet follows isentropic surfaces, increasing in altitude as it moves northward toward the Texas coast. 


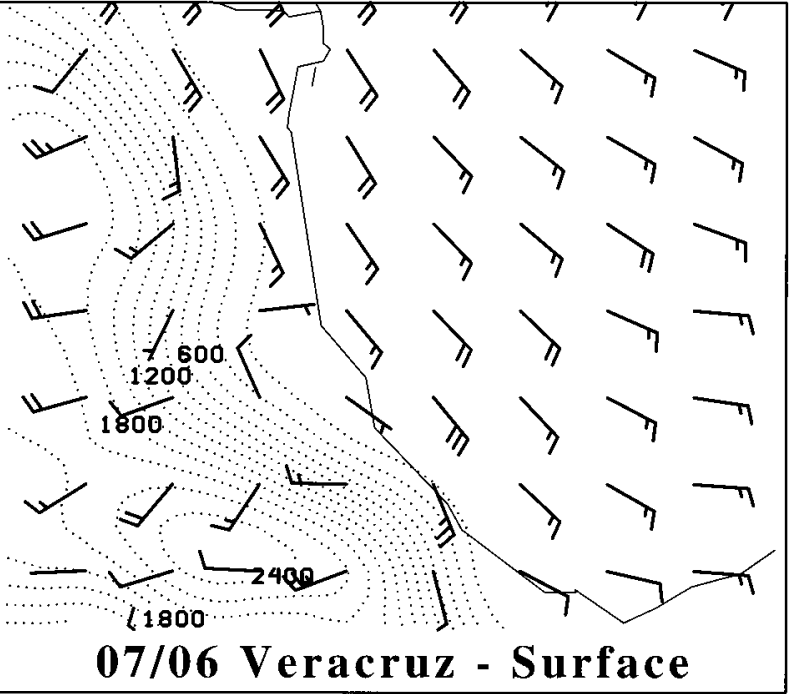

FIG. 17. Lowest model-level winds (at alternating model grid points) and surface elevation, showing Veracruz jet reaching the surface north of the eastern edge of the Neovolcanic Cordillera and a small eddy west of the jet in the lee of the cordillera.

wind speed maxima which form south of the United States during periods of return flow. The processes leading to the formation of these additional LLJs are quite different from those associated with the quiescent Plains jet and are directly related to both the topography and the evolution of the synoptic-scale environment.

The low-level pressure gradient associated with the Brownsville jet is established when the air atop the widest portion of the Mexican High Plain is heated during the day and advected northeastward in advance of an approaching upper-level mobile trough (Fig. 18). The southern end of the Brownsville jet in the simulation is located at 850-900 mb over the sloping terrain at the base of the Sierra Madre Oriental about $250 \mathrm{~km}$ southwest of Brownsville, and the jet extends northward into the United States west of Brownsville. This jet may be partly responsible for the secondary maximum of LLJ frequency at Brownsville reported by Bonner (1968), although this particular LLJ would have been missed by the rawinsonde observing network because the distance between sites is too great. The relative scarcity of observations over northeastern Mexico may also explain why Djurić and Damiani (1980) and Djurić and Ladwig (1983) described the Plains LLJ as developing upstream to Brownsville and forming a secondary maximum there, in contrast to our simulation which shows the Brownsville jet developing on the first day simultaneously with the Plains jet. Our Brownsville jet did not move over the Brownsville rawinsonde site until the third night.

While the elevated mixed layer contributed to the Veracruz jet as well, orographic blocking of the flow appeared to be the primary cause of the Veracruz jet. As air traveled up the Gulf coast from Yucatan and the

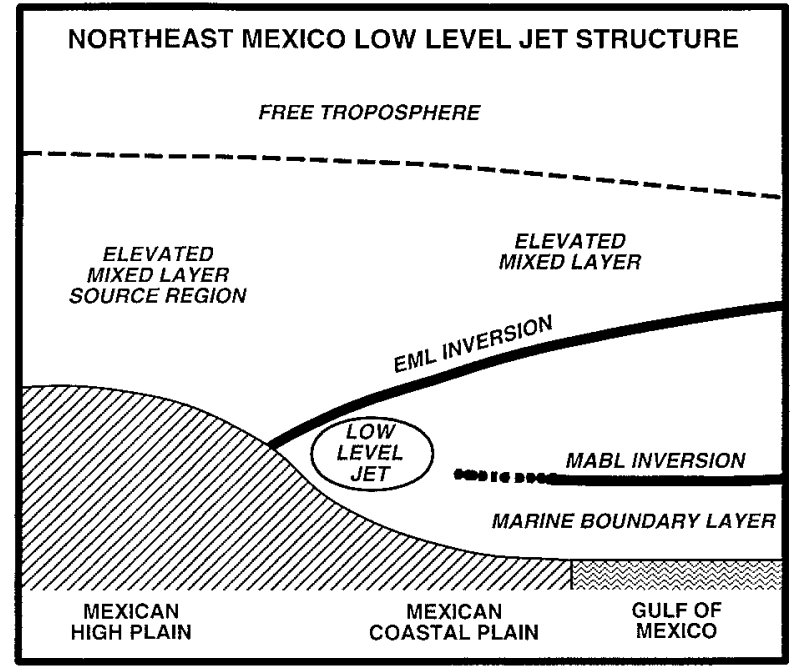

FIG. 18. Conceptual model of thermal structure and associated LLJ during the early stages of return flow through northeastern Mexico: $\mathrm{EML}=$ elevated mixed layer; $\mathrm{MABL}=$ marine atmospheric boundary layer.

Isthmus of Tehuantepec, it was obstructed by the eastern end of the Neovolcanic Cordillera, causing a local enhancement in low-level winds over the extreme western Gulf of Mexico. This LLJ was the most stationary of the three southerly LLJs in the simulation, indicating its topographic origins. Although the obstruction is not as significant, the Sierra Madre Oriental may also contribute to the strength of the Brownsville jet in a similar manner.

Low-level jets have been an interesting area of investigation not because it is difficult to find a possible mechanism for LLJ formation but because there are so many mechanisms that can contribute to low-level wind maxima. This simulation demonstrates the varying roles the different mechanisms play in different locations and different times.

Nighttime frictional decoupling should operate everywhere, but will be most effective where the geostrophic wind is strongest near the base of the boundary layer. This configuration was found in the Plains jet of the first night, and the simulated inertial oscillation was strongest then. As westerlies intensify aloft, the temperature gradient associated with the low-level geostrophic wind maximum becomes the sloping base of the EML. The LLJ deepens and becomes less sensitive to changes in surface friction and more sensitive to changes in the slope and intensity of the EML inversion.

The elevated mixed-layer extends eastward across a large portion of the southern Plains and eastern Mexico, but should be warmest downstream of the elevated heating area of the Mexican High Plain, particularly the wide plateau region in north-central Mexico. This enhanced heating appears to be the primary cause of the local enhancement of the low-level pressure gradient downstream of that region, southwest of Brownsville. The 
timing of the Brownsville jet, or any jet associated with an EML, depends on the development of cross-mountain flow to advect mixed-layer air downstream above the lower terrain. Therefore, while we have described the jet as a phenomenon related to local adjustments to elevated heating, its formation also requires the suitable synoptic-scale cross-mountain flow. The strength of the Brownsville jet also varied diurnally, in association with changes in the strength and slope of the inversion. This view of the inversion capping the LLJ contrasts with that of Djurić and Damiani (1980), who indicated that the LLJ forms under a subsidence inversion.

The strength of the cross-mountain flow also governs the amount of small-scale structure within the LLJ. While the southerly flow is adjacent to the eastern slope of the Mexican High Plain, the irregularities in the topography modulate the speeds within the LLJ, even to the extent of causing a separate pronounced wind maximum north of Veracruz. As the cross-mountain flow intensifies and the lee trough develops over the coastal plain, the southerly airflow no longer impinges on the High Plain slope and the LLJ evolves into a broad, straight band of high winds.

This return flow cycle also involved cyclogenesis over the Plains and a severe weather outbreak. Both cyclogenesis and latent heat release would be associated with low-level southerly ageostrophic winds (Uccellini 1980; Nicolini et al. 1993). These processes may have contributed somewhat to the strength of the LLJs, but the jets of this simulation were not strongly supergeostrophic during the period of cyclogenesis during the second and third day.

Determination of the generality of these results would involve some combination of higher-resolution simulations and direct observations in a field program. However, it seems reasonable to expect that, to the extent that the processes described above are operating in northern and central Mexico, LLJs should be produced by them in a manner similar to that found in the model simulation. Even if the modeled LLJs are not realistic, we can conclude that an accurate representation of the topography and land surface characteristics over Mexico are necessary for the accurate simulation of the Brownsville and Veracruz jets. Producing an accurate numerical forecast would require an accurate analysis of the structure of the EML, its underlying inversion, and the winds beneath the inversion. In addition, the model must be capable of accurately simulating the interaction of the diurnal heating cycle with the topography and the synoptic-scale airflow.

Acknowledgments. The authors would like to thank the following: Dr. John Lanicci for supplying the model output and providing technical/scientific help regarding the data; Mike Nelson for all the programming help; and Svetla Veleva for her "intellectual exercises" on the topic. We also thank Dr. Jim Scoggins, Dr. Dušan Djurić, Dr. Robert Maddox, and the reviewers for their interest and suggestions regarding this work. This research was supported by the Cooperative Institute for Applied Meteorological Studies through a grant from the National Oceanic and Atmospheric Administration (NOAA Contract NA37WA0543).

\section{REFERENCES}

Anthes, R. A., 1977: A cumulus parameterization scheme utilizing a one-dimensional cloud model. Mon. Wea. Rev., 105, 270-286.

, E.-Y. Hsie, and Y.-H. Kuo, 1987: Description of the Penn State/ NCAR Mesoscale Model Version 4 (MM4). NCAR Tech. Note NCAR/TN-282+STR, National Center for Atmospheric Research, Boulder, CO, 66 pp. [Available from NCAR, P.O. Box 3000, Boulder, CO 80307.]

Arritt, R. W., J. M. Wilczak, and G. S. Young, 1992: Observations and numerical modeling of an elevated mixed layer. Mon. Wea. Rev., 120, 2869-2880.

Augustine, J. A., and F. Caracena, 1994: Lower-tropospheric precursors to nocturnal MCS development over the central United States. Wea. Forecasting, 9, 116-135.

Bannon, P. R., 1979: On the dynamics of the East African jet. Part I: Simulation of the mean conditions for July. J. Atmos. Sci., 36, 2139-2152.

Benjamin, S. G., 1983: Some effects of surface heating and topography on the regional severe storm environment. Ph.D. thesis, The Pennsylvania State University, 265 pp. [Available from Department of Meteorology, The Pennsylvania State University, University Park, PA 16802.]

- 1986: Some effects of surface heating and topography on the regional severe-storm environment. Part II: Two-dimensional idealized experiments. Mon. Wea. Rev., 114, 330-343.

— topography on the regional severe-storm environment. Part I: Three-dimensional simulations. Mon. Wea. Rev., 114, 307-329.

Blackadar, A. K., 1957: Boundary layer wind maxima and their significance for the formation of nocturnal inversions. Bull. Amer. Meteor. Soc., 38, 283-290.

_ 1979: High resolution models of the planetary boundary layer. Advances in Environmental Science and Engineering, J. Pfafflin and E. Ziegler, Eds., Vol. 1, Gordon and Breach Science Publishers, 50-85.

Bonner, W. D., 1968: Climatology of the low-level jet. Mon. Wea. Rev., 96, 833-850.

- and J. Paegle, 1970: Diurnal variations in boundary layer winds over the south-central United States in summer. Mon. Wea. Rev., 98, 735-744.

Carlson, T. N., and F. H. Ludlam, 1968: Conditions for the formation of severe local storms. Tellus, 20, 203-226.

_ R. A. Anthes, M. Schwartz, S. G. Benjamin, and D. G. Baldwin, 1980: Analysis and prediction of severe storms environment. Bull. Amer. Meteor. Soc., 61, 1018-1032.

_ , S. G. Benjamin, G. S. Forbes, and Y.-F. Li, 1983: Elevated mixed layer in the severe-storm environment-Conceptual model and case studies. Mon. Wea. Rev., 111, 1453-1473.

Crisp, C. A., and J. M. Lewis, 1992: Return flow in the Gulf of Mexico. Part I: A classificatory approach with a global historical perspective. J. Appl. Meteor., 31, 868-881.

Djurić, D., and M. S. Damiani Jr., 1980: On the formation of the low-level jet over Texas. Mon. Wea. Rev., 108, 1854-1865.

_ cyclones of the southwestern Great Plains. Mon. Wea. Rev., 111, 2275-2281.

Eddington, L. T., J. J. Obrien, and D. W. Stuart, 1992: Numerical simulation of topographically forced variability in a well-mixed marine layer. Mon. Wea. Rev., 120, 2881-2896.

Engel, G. T., 1991: Low-level wind maxima over the western Gulf of Mexico and their role in water vapor advection. M.S. thesis, Department of Meteorology, Texas A\&M University, 122 pp. 
[Available from Dept. of Meteorology, Texas A\&M University, College Station, TX 77843-3150.]

Fast, J. D., and M. D. McCorcle, 1990: A two-dimensional numerical sensitivity study of the Great Plains low-level jet. Mon. Wea. Rev., 118, 151-163.

Frisch, A. S., B. W. Orr, and B. E. Martner, 1992: Doppler radar observations of the development of a boundary-layer nocturnal jet. Mon. Wea. Rev., 120, 3-16.

Ghan, S. J., X. Bian, and L. Corsetti, 1996: Simulation of the Great Plains low-level jet and associated clouds by general circulation models. Mon. Wea. Rev., 124, 1388-1408.

Helfand, H. M., and S. D. Schubert, 1995: Climatology of the simulated Great Plains low-level jet and its contribution to the continental moisture budget of the United States. J. Climate, 8, 784806

Hobbs, P. V., J. D. Locatelli, and J. E. Martin, 1996: A new conceptual model for cyclones generated in the lee of the Rocky Mountains. Bull. Amer. Meteor. Soc., 77, 1169-1178.

Holton, J. R., 1967: The diurnal boundary layer wind oscillation above sloping terrain. Tellus, 19, 199-205.

Janish, P. R., and S. W. Lyons, 1992: NGM performance during coldair outbreaks and periods of return flow over the Gulf of Mexico with emphasis on moisture-field evolution. J. Appl. Meteor., 31, 995-1017.

Kuo, H. L., 1974: Further studies of the parameterization of the influence of cumulus convection on large-scale flow. J. Atmos. Sci., 31, 1232-1240.

Lanicci, J. M., 1991: A synoptic climatology of the elevated mixed layer inversion over the southern Great Plains in spring. Ph.D. thesis, The Pennsylvania State University, 290 pp. [Available from Department of Meteorology, The Pennsylvania State University, University Park, PA 16802.]

_ , and T. T. Warner, 1991: A synoptic climatology of the elevated mixed-layer inversion over the southern Great Plains in spring. Part II: The life cycle of the lid. Wea. Forecasting, 6, 198-213. , and _ 1997: A case study of lid evolution using analyses of observational data and a numerical model simulation. Wea. Forecasting, 12, 228-252.

_, T. N. Carlson, and T. T. Warner, 1987: Sensitivity of the Great Plains severe-storm environment to soil-moisture distribution. Mon. Wea. Rev., 115, 2660-2673.

Martin, J. E., J. D. Locatelli, P. V. Hobbs, W. Peng-Yun, and J. A. Castle, 1995: Structure and evolution of winter cyclones in the central United States and their effects on the distribution of precipitation. Part I: A synoptic-scale rainband associated with a dryline and lee trough. Mon. Wea. Rev., 123, 241-264.

McCorcle, M. D., 1988: Simulation of surface moisture effects on the Great Plains low-level jet. Mon. Wea. Rev., 116, 1705-1720.

McNider, R. T., and R. A. Pielke, 1981: Diurnal boundary-layer development over sloping terrain. J. Atmos. Sci., 38, 2198-2212.

Mitchell, M. J., R. W. Arritt, and K. Labas, 1995: A climatology of the warm season Great Plains low-level jet using wind profiler observations. Wea. Forecasting, 10, 576-591.

Nicolini, M., K. M. Waldron, and J. Paegle, 1993: Diurnal oscillations of low-level jets, vertical motion, and precipitation: A model case study. Mon. Wea. Rev., 121, 2588-2610.

Ookouchi, Y., M. Segal, R. C. Kessler, and R. A. Pielke, 1984: Evaluation of effects on the generation and modification of mesoscale circulations. Mon. Wea. Rev., 112, 2281-2292.

Paegle, J., and G. E. Rasch, 1973: Three-dimensional characteristics of diurnally varying boundary layer flows. Mon. Wea. Rev., 101, 746-756.

Parish, T. R., A. R. Rodi, and R. D. Clark, 1988: A case study of the summertime Great Plains low-level jet. Mon. Wea. Rev., 116, 94-105.

Parmenter, F. C., 1976: Evidence of a low-level jet stream in the western Gulf of Mexico. Preprints, Seventh Conf. on Aerospace and Aeronautical Meteorology and Symp. on Remote Sensing from Satellites, Melbourne, Australia, Amer. Meteor. Soc., 312317.

Savijärvi, H., 1991: The United States Great Plains diurnal ABL variation and the nocturnal low-level jet. Mon. Wea. Rev., 119, 833-840.

Schaefer, J. T., 1974: The life cycle of the dryline. J. Appl. Meteor., 13, 444-449.

Smolarkiewicz, P. K., and R. Rotunno, 1989: Low Froude number flow past three-dimensional obstacles. Part I: Baroclinically generated lee vortices. J. Atmos. Sci., 46, 1154-1164

Tilley, J. S., 1990: On the application of edge wave theory to terrainbounded cold surges: A numerical study. Ph.D. thesis, The Pennsylvania State University, 353 pp. [Available from Dept. of Meteorology, The Pennsylvania State University, University Park, PA 16802.]

Uccellini, L. W., 1980: On the role of upper tropospheric jet streaks and low-level jets in the Great Plains. Mon. Wea. Rev., 108, $1689-1696$.

— , and D. R. Johnson, 1979: The coupling of upper and lower tropospheric jet streams and implications for the development of severe convective storms. Mon. Wea. Rev., 107, 682-703.

Weiss, S. J., 1992: Some aspects of forecasting severe thunderstorms during cool-season return-flow episodes. J. Appl. Meteor., 31, 964-982.

Wexler, H., 1961: A boundary layer interpretation of the low-level jet. Tellus, 13, 368-378.

Yan, H., and R. A. Anthes, 1988: The effect of variations in surface moisture on mesoscale circulations. Mon. Wea. Rev., 116, 192208.

Zeman, O., 1979: Parameterization of the dynamics of stable boundary layers and nocturnal jets. J. Atmos. Sci., 36, 792-804.

Zhang, D.-L., and R. A. Anthes, 1982: A high-resolution model of the planetary boundary layer-Sensitivity tests and comparisons with SESAME-79 data. J. Appl. Meteor., 21, 1594-1609.

Zhong, S., J. D. Fast, and X. Bian, 1996: A case study of the Great Plains low-level jet using wind profiler network data and a highresolution mesoscale model. Mon. Wea. Rev., 124, 785-806. 